\title{
CROPS AND SOILS RESEARCH PAPER \\ Comparative performance of the stable isotope signatures of carbon, nitrogen and oxygen in assessing early vigour and grain yield in durum wheat
}

\author{
J. BORT ${ }^{1 *}, M . B E L H A J^{2}, K . L A T I R I^{2}$, Z. KEHEL ${ }^{3}$ AND J. L. ARAUS ${ }^{1}$ \\ ${ }^{1}$ Plant Biology Department, Faculty of Biology, University of Barcelona, Diagonal 643, 08028 Barcelona, Spain \\ ${ }^{2}$ INRAT, Field Crops Laboratory, Rue Hédi Karray, 2049 Ariana, Tunisia \\ ${ }^{3}$ Biodiversity and Integrated Gene Management, International Centre for Agricultural Research in the Dry Areas (ICARDA), \\ PO Box 5466, Aleppo, Syria
}

(Received 23 July 2012; revised 22 March 2013; accepted 16 April 2013)

\section{SUMMARY}

The present paper studied the performance of the stable isotope signatures of carbon $\left(\delta^{13} \mathrm{C}\right)$, nitrogen $\left(\delta^{15} \mathrm{~N}\right)$ and oxygen $\left(\delta^{18} \mathrm{O}\right)$ in plants when used to assess early vigour and grain yield (GY) in durum wheat growing under mild and moderate Mediterranean stress conditions. A collection of 114 recombinant inbred lines was grown under rainfed (RF) and supplementary irrigation (IR) conditions. Broad sense heritabilities $\left(H^{2}\right)$ for $G Y$ and harvest index $(\mathrm{HI})$ were higher under RF conditions than under IR. Broad sense heritabilities for $\delta^{13} \mathrm{C}$ were always above $0 \cdot 60$, regardless of the plant part studied, with similar values for IR and RF trials. Some of the largest genetic correlations with GY were those shown by the $\delta^{13} \mathrm{C}$ content of the flag leaf blade and mature grains. Under both water treatments, mature grains showed the highest negative correlations between $\delta^{13} \mathrm{C}$ and $\mathrm{GY}$ across genotypes. Flag leaf $\delta^{13} \mathrm{C}$ was negatively correlated with GY only under RF conditions. The $\delta^{13} \mathrm{C}$ in seedlings was negatively correlated, under IR conditions only, with GY but also with early vigour. The sources of variation in early vigour were studied by stepwise analysis using the stable isotope signatures measured in seedlings. The $\delta^{13} \mathrm{C}$ was able to explain almost $0 \cdot 20$ of this variation under RF, but up to 0.30 under IR. In addition, nitrogen concentration in seedlings accounted for another 0.05 of variation, increasing the amount explained to $0 \cdot 35$. The sources of variation in GY were also studied through stable isotope signatures and biomass of different plant parts: $\delta^{13} \mathrm{C}$ was always the first parameter to appear in the models for both water conditions, explaining c. $0 \cdot 20$ of the variation. The second parameter $\left(\delta^{15} \mathrm{~N}\right.$ or $\mathrm{N}$ concentration of grain, or biomass at maturity) depended on the water conditions and the plant tissue being analysed. Oxygen isotope composition $\left(\delta^{18} \mathrm{O}\right)$ was only able to explain a small amount of the variation in GY. In this regard, despite the known and previously described value of $\delta^{13} \mathrm{C}$ as a tool in breeding, $\delta^{15} \mathrm{~N}$ is confirmed as an additional tool in the present study. Oxygen isotope composition does not seem to offer any potential, at least under the conditions of the present study.

\section{INTRODUCTION}

Durum wheat (Triticum durum L.) is one of the most widely cultivated crops in the Mediterranean basin, where drought is the main abiotic stress limiting its production (Araus et al. 2002, 2003). The Mediterranean climate is characterized by drought (a combination of water stress, high temperatures and excess radiation) during late spring, coinciding with

* To whom all correspondence should be addressed. Email: jordi. bort@ub.edu the grain filling of cereal crops (Acevedo et al. 1999). Knowledge of the physiological traits responsible for adaptation of durum wheat cultivars to Mediterranean environments may be relevant for future breeding strategies.

In the case of $\mathrm{C}_{3}$ cereals grown under Mediterranean conditions, although vegetative growth takes place at low vapour pressure deficit (VPD) and (eventually) with good soil moisture conditions, grain filling is almost always affected by late drought, associated with high irradiances and temperatures, together with a lack 
of precipitation. The use of less water to achieve high yield is a major objective of modern agriculture (Richards et al. 2001; Araus 2004). The present study addresses some plant physiological aspects related to achieving increased water-use efficiency (WUE) in cereal crops.

Plant breeding in general, and cereal breeding in particular, have been remarkably successful during the second half of the 20th century, contributing substantially to keeping production ahead of population growth in spite of the world population increasing more rapidly than ever before (more than doubling in half a century). However, this pattern of increase has declined in recent years (Araus et al. 2008; Foulkes et al. 2011). Moreover, climate change will probably increase the impact of drought markedly in the Mediterranean basin, which may further constrain the productivity of durum wheat and other cereals.

While genetic increases in yield potential are best expressed in optimum environments, they are also associated with enhanced yields under drought (Araus et al. 2002; Trethowan et al. 2002; Slafer \& Araus 2007; Latiri et al. 2010). However, it is still debatable whether traits conferring higher yield potential can offer some advantages under drought conditions (Tambussi et al. 2005b; Araus et al. 2008).

Capturing more soil water and utilizing stem reserves for grain filling under stress were highlighted by Blum (2006) as the primary factors responsible for superior performance of drought-adapted cereal cultivars.

For a secondary trait to be useful in a breeding programme (Bänziger et al. 2000; Araus et al. 2008), it must comply with several requirements: (1) it must be genetically correlated with grain yield (GY) in the environmental conditions of the target environment, that is to say, the relationship with yield must be causal not casual; (2) it should be less affected by environment than GY, i.e. it should have greater heritability than yield itself, and less genotype by environment interaction; and (3) enough genetic variability for the target trait to have worthwhile potential for genetic improvement.

The carbon $(\mathrm{C})$ isotope composition $\left(\delta^{13} \mathrm{C}\right)$ of plant dry matter, which is frequently expressed as the discrimination value $\left(\Delta^{13} \mathrm{C}\right)$, was proposed more than 20 years ago as a potential tool for screening wheat genotypes with higher transpiration efficiency (TE) (Farquhar \& Richards 1984; Rebetzke et al. 2002). Assuming the isotopic $\mathrm{C}$ composition of atmospheric carbon dioxide $\left(\mathrm{CO}_{2}\right)$ is constant then the $\delta^{13} \mathrm{C}$ of plant dry matter itself may be used as an indicator of WUE. The first genotypes selected using high $\delta^{13} \mathrm{C}$ (or low $\Delta^{13} \mathrm{C}$ ) as a selection trait for high WUE were subsequently released in Australia (Rebetzke et al. 2002; Condon et al. 2004). However, $\delta^{13} \mathrm{C}$ may be affected by water status (through stomatal conductance) as well as by intrinsic photosynthetic capacity, driven for example by the amount of carboxylating enzyme (Rao et al. 1995; Condon et al. 2002).

Vigorous crop establishment is agronomically desirable as it helps to shade the soil, preventing direct evaporation from it and suppressing weeds that compete for water, therefore increasing the efficient use of water (Blum 2009). Rapid groundcover is a crucial component and can be achieved by breeding for thinner, wider leaves, a more prostrate growth habit (Richards et al. 2002), lower nitrogen (N) content per unit leaf area (Tambussi et al. 2005b), large seed and embryo size (Aparicio et al. 2002) and longer coleoptiles (Rebetzke et al. 2005, 2008). Following some early references to the relationship between early vigour and $\delta^{13} \mathrm{C}$ (Febrero et al. 1993; Richards et al. 1993), a range of results has been obtained. Bort et al. (1998) did not find any correlation between early vigour and $\delta^{13} \mathrm{C}$, possibly due to the effect of low temperatures at the time when assessment of early vigour and leaf structure was being performed under field conditions. In contrast, both Condon \& Richards (1992) and Rebetzke et al. (2002) described strong genetic correlations between $\delta^{13} \mathrm{C}$ and both $\mathrm{GY}$ and aerial biomass measured at the commencement of stem elongation. Genotypes with lower $\delta^{13} \mathrm{C}$ (and higher GY potential) may still show higher GY under drought if lower $\delta^{13} \mathrm{C}$ values are associated with higher water availability through increased root growth and early vigour (Villegas et al. 2000; Tambussi et al. 2005b).

Natural variation in plant $\mathrm{N}$ isotope composition $\left(\delta^{15} \mathrm{~N}\right)$ has been proposed as a useful trait for screening as it is linked to plant $\mathrm{N}$ metabolism, even though there is no precise knowledge of the underlying mechanisms or function (Handley et al. 1997; Robinson et al. 2000; Ellis et al. 2002; Pritchard \& Guy 2005; Coque et al. 2006). Robinson et al. (2000) proposed that measuring the natural abundance of both ${ }^{13} \mathrm{C}$ and ${ }^{15} \mathrm{~N}$ may give an indication of responses to stresses such as drought and $\mathrm{N}$ starvation. Moreover, both $\delta^{13} \mathrm{C}$ and $\delta^{15} \mathrm{~N}$ have been used to phenotype the response of barley mapping populations to salinity, as the natural abundances of these isotopes are strongly affected by salinity and there is genotypic variability in both stable 
isotopes (Ellis et al. 1997, 2002; Handley et al. 1997). Yousfi et al. (2009) recently reported a good correlation between genotypic differences in biomass and $\delta^{15} \mathrm{~N}$ for durum wheat grown under moderate salinity.

The oxygen $(\mathrm{O})$ isotope composition $\left(\delta^{18} \mathrm{O}\right)$ of organic matter is known to reflect variation in: (i) the isotopic composition of source water; (ii) evaporative enrichment in leaves due to transpiration; and (iii) biochemical fractionation during synthesis of organic matter (Craig \& Gordon 1965; Dongmann et al. 1974; Yakir 1992; Farquhar \& Lloyd 1993). Hence, the oxygen isotope signature of plant matter, expressed either as composition $\left(\delta^{18} \mathrm{O}\right)$ or as enrichment above source water $\left(\Delta^{18} \mathrm{O}\right)$, has been used to assess the leaf evaporative conditions at the time the material was formed (Yakir \& DeNiro 1990; Yakir et al. 1990; Yakir 1992; Saurer et al. 1997; Barbour et al. 2000a,b; Barbour 2007). A lower $\delta^{18} \mathrm{O}$ (Barbour et al. 2000a), together with a lower $\delta^{13} \mathrm{C}$ (Fischer et al. 1998) have been associated with a higher yield potential in bread wheat, suggesting that the genotypes exhibiting higher yield keep their stomata more open and probably exhibit a higher water use. However, the use of $\delta^{18} \mathrm{O}$ for genotype selection under drought stress has had much less investigation.

Cabrera-Bosquet et al. $(2009,2011)$ recently illustrated the usefulness of combining $\delta^{18} \mathrm{O}$ and $\delta^{13} \mathrm{C}$ in wheat in order to assess differences in plant growth and total transpiration, and also to provide a timeintegrated record of the photosynthetic and evaporative performance of the plant during the course of crop growth. However, these studies were carried out with a limited number of genotypes grown in pots (CabreraBosquet et al. 2009) or under field conditions (CabreraBosquet et al. 2011) with a single genotype. Under field conditions on a set of 24 genotypes of bread wheat Ferrio et al. (2007) failed to identify genotypic variability in isotope composition. Recently, Condon (2012) failed to find differences in $\delta^{18} \mathrm{O}$ between water treatments, possibly due to the small treatment difference in subsoil water use.

The current work presents GY and its agronomic components, biomass and the stable isotope signatures of $\mathrm{C}, \mathrm{N}$ and $\mathrm{O}$ in different plant parts from a collection of recombinant inbred lines (RIL) of durum wheat grown under supplementary water supply and moderate water stress. The two trials (IR and RF) reported in the present study belong to a wider set of trials reported in Kehel et al. (2010), but analysis of the stable isotope compositions of $\mathrm{C}, \mathrm{N}$ and $\mathrm{O}$ is unique to the present work. The objective of the present study was to compare how the three different isotope signatures performed in predicting genotypic differences in early vigour and grain yield.

\section{MATERIALS AND METHODS}

A field experiment was conducted during the 2004/05 season in Oued Souhil, Nabeul, in the Cap Bon peninsula, northern Tunisia $\left(10^{\circ} 40^{\prime} \mathrm{E}, 36^{\circ} 27^{\prime} \mathrm{N}, 24 \mathrm{~m}\right.$ a.s.l.). The climatic area is described as semi-arid. During the growing season, rainfall was $235 \mathrm{~mm}$, average daily temperature between 10 and $25^{\circ} \mathrm{C}$ and total evaporation was $530 \mathrm{~mm}$ (Fig. 1). Soil texture was very sandy and was a homogeneous fluvisol of low organic matter content and low water-holding capacity. Its agronomic characteristics could be described as leading to terminal stresses with low productivity.

\section{Plant material}

The durum wheat (Triticum turgidum L. ssp. durum (Desf.) Husn.) population used in the present study consisted of 112 RILs derived from the cross Lahn $\times$ Cham 1 using the single seed descent (SSD) method from the cross identification number ICDMN91-0015 (ICARDA 2004), plus the two parents. Lahn is also known as Jennah Khetifa (Yousfi et al. 2009). This cross was made in 1991 at the Tel Hadya research station (Aleppo province, Syria) by the CIMMYT/ICARDA durum breeding programme for Mediterranean dryland areas (Nachit et al. 2001). The Lahn parent is a highly productive cultivar with a maximum yield of up to $12 \mathrm{t} / \mathrm{ha}$ and has a strong stem with high lodging resistance, large grain size and good grain quality. The Cham1 parent has good drought tolerance, showed durable resistance to yellow rust and high yield stability in Mediterranean environments; it has been released in most Mediterranean countries, from Portugal to Iraq (west to east) and from Turkey to Sudan (north to south) (Kehel et al. 2010).

\section{Growth conditions}

Plants were grown under field conditions. Sowing was conducted on 16-17 December 2004 with a total of 144 plots per water treatment. The whole set of plots of each water treatment was surrounded by plots containing local commercial varieties. Each plot consisted of six rows, $2.5 \mathrm{~m}$ long with $400 \mathrm{~mm}$ between rows.

The 112 RILs were tested in unreplicated field trials, adopting a modified augmented design as a field 


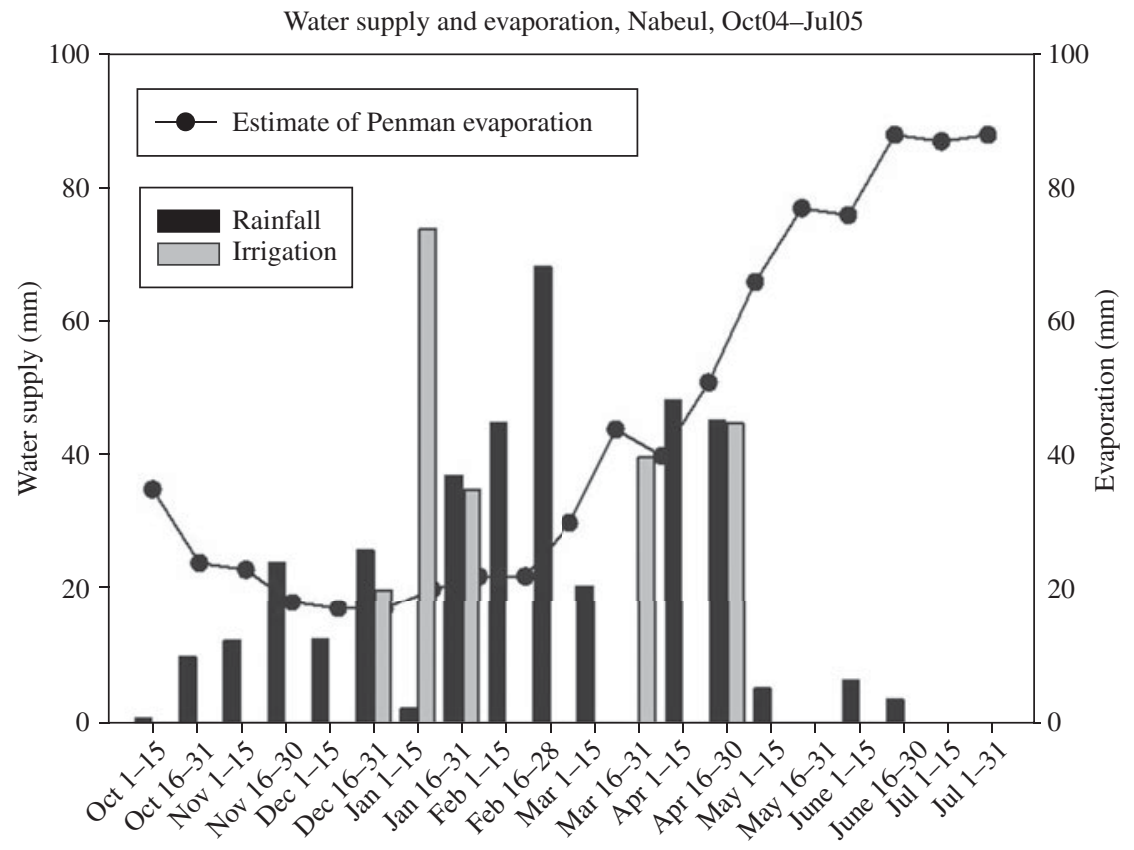

Fig. 1. Weather conditions during the growing season in Nabeul, where irrigation events are shown (clear bars) Estimates of Penman evaporation were calculated, and amounts of water supply (rainfall and irrigation) are shown in 2-weeks periods, from October 2004 to July 2005.

\begin{tabular}{|l|c|c|c|c|c|c|c|c|c|c|c|c|c|}
\hline Control & Control & Control & Control & Control & Control & Control & Control & Control & Control & Control & Control & Control & Control \\
\hline Control & 144 & 143 & 142 & 141 & 140 & 139 & 138 & 137 & 136 & 135 & 134 & 133 & Control \\
\hline Control & 121 & 122 & 123 & 124 & 125 & 126 & 127 & 128 & 129 & 130 & 131 & 132 & Control \\
\hline Control & 120 & 119 & 118 & 117 & 116 & 115 & 114 & 113 & 112 & 111 & 110 & 109 & Control \\
\hline Control & 97 & 98 & 99 & 100 & 101 & 102 & 103 & 104 & 105 & 106 & 107 & 108 & Control \\
\hline Control & 96 & 95 & 94 & 93 & 92 & 91 & 90 & 89 & 88 & 87 & 86 & 85 & Control \\
\hline Control & 73 & 74 & 75 & 76 & 77 & 78 & 79 & 80 & 81 & 82 & 83 & 84 & Control \\
\hline Control & 72 & 71 & 70 & 69 & 68 & 67 & 66 & 65 & 64 & 63 & 62 & 61 & Control \\
\hline Control & 49 & 50 & 51 & 52 & 53 & 54 & 55 & 56 & 57 & 58 & 59 & 60 & Control \\
\hline Control & 48 & 47 & 46 & 45 & 44 & 43 & 42 & 41 & 40 & 39 & 38 & 37 & Control \\
\hline Control & 25 & 26 & 27 & 28 & 29 & 30 & 31 & 32 & 33 & 34 & 35 & 36 & Control \\
\hline Control & 24 & 23 & 22 & 21 & 20 & 19 & 18 & 17 & 16 & 15 & 14 & 13 & Control \\
\hline Control & 1 & 2 & 3 & 4 & 5 & 6 & 7 & 8 & 9 & 10 & 11 & 12 & Control \\
\hline Control & Control & Control & Control & Control & Control & Control & Control & Control & Control & Control & Control & Control & Control \\
\hline
\end{tabular}

Fig. 2. Experimental design of the trial: unreplicated augmented design, with a commercial cultivar surrounding the trial. Coloured plots indicate those with 6 control cultivars (cvars Mrb5, pink; Gidara-2, green; Hau, orange; Krf, grey and Waha, green). Plot numbers 143 and 144 correspond to the parents of the genotype collection (Lahn and Cham-1, respectively). White plots correspond to the 112 RILs. The design was repeated for the two water treatments: the only difference between RF and IR was how the 112 RILs were distributed within the white plots. (Colour version available online.)

experimental scheme (Fig. 2), including six replicates of each of the five controls (cvars Mrb5, Gidara-2, Hau, Krf and Waha). The two parents of the collection, Lahn and Cham-1, were also included in single plots (numbers 143 and 144). The randomization of the RILs within each set of 112 plots was different for each water treatment.

Fertilization with phosphorous (P) was conducted as a single supply of $45 \mathrm{~kg} \mathrm{P}_{2} \mathrm{O}_{5} / \mathrm{ha}(100 \mathrm{~kg}$ of triple superphosphate 'Super 45 Granule' with total $0 \cdot 45$ phosphoric anhydride) on 29 Nov 2005, 2 weeks before sowing. Nitrogen was supplied as ammonium nitrate, split into two doses of $100 \mathrm{~kg} / \mathrm{ha}$ each, on 19 Jan 2005 (three leaves (3L)) and in mid-February (five leaves (5L)).

The two different treatments, irrigated (IR) and rainfed (RF), were adjacent to each other but separated by a distance of $10 \mathrm{~m}$. Shortly after sowing (27 Dec 
2005) an initial flood irrigation of $20 \mathrm{~mm}$ was supplied to ensure uniform germination and emergence for both IR and RF. The RF trial only received $10 \mathrm{~mm}$ of irrigation on 17 Jan 2006, whereas IR received an additional $22 \mathrm{~mm}$ on 8 Jan, $22 \mathrm{~mm}$ on 10 Jan, $30 \mathrm{~mm}$ on 13 Jan, $35 \mathrm{~mm}$ on 17 Jan, $40 \mathrm{~mm}$ on $22 \mathrm{Mar}, 5 \mathrm{~mm}$ on $23 \mathrm{Apr}$ and $45 \mathrm{~mm}$ on $29 \mathrm{Apr} 2006$. Total water supplied was $218 \mathrm{~mm}$ and $30 \mathrm{~mm}$ to the IR and RF treatments, respectively. In addition, the accumulated rainfall between sowing to harvest (end of December to end of June) was $235 \mathrm{~mm}$.

\section{Data recording}

For each plot, the whole aerial part of each plant was collected from a $0.5 \mathrm{~m}$ length of a single row, at the $3 \mathrm{~L}$ and six-leaf (6L) stages, from $1 \mathrm{~m}$ of a single row at anthesis, and from $2.5 \mathrm{~m}$ of three adjacent rows at harvest. Complementary observations were made on subsamples of ten plants at the $3 \mathrm{~L}$ stage, the $6 \mathrm{~L}$ stage and anthesis. All samples were oven-dried at $80^{\circ} \mathrm{C}$ for $48 \mathrm{~h}$ before being weighed and ground to a fine powder for stable isotope analysis.

Total plant aerial biomass was measured in seedlings at the $3 \mathrm{~L}$ and the $6 \mathrm{~L}$ stages as well as at anthesis and harvest. Total aerial biomass and GY were measured from the three central rows of each plot at maturity. Further the harvest index $(\mathrm{HI})$ was calculated as the ratio of GY to total shoot biomass. Other yield components (spikes $/ \mathrm{m}^{2}$, thousand grain weight (TGW) and grains $/ \mathrm{m}^{2}$ ) were also calculated.

\section{Stable isotope analysis}

\section{Total N content and C and N isotope analyses}

For each analysis, $1 \mathrm{mg}$ of finely powdered plant tissue, i.e. seedling (6L stage), flag leaf blade, and mature grain tissue was weighed in tin cups. The total $\mathrm{N}$ content of samples was analysed at the Colorado Plateau Stable Isotope Laboratory (CPSIL) using an Elemental Analyser (EA) (Carlo Erba 2100, Milan, Italy). The same EA, interfaced with an isotope ratio mass spectrometer (IRMS) (Thermo-Finnigan Deltaplus Advantage, Bremen, Germany), was also used to analyse the ${ }^{13} \mathrm{C} /{ }^{12} \mathrm{C}$ ratios (R) of plant material. Results were expressed as $\delta^{13} \mathrm{C}$ values using a secondary standard calibrated against Vienna Pee Dee Belemnite calcium carbonate (VPDB), and the analytical precision was $0 \cdot 1 \%$.

$$
\delta^{13} \mathrm{C}(\% \mathrm{o})=\left[\left(\frac{R_{\text {sample }}}{R_{\text {Standard }}}\right)-1\right] \times 1000
$$

The same $\delta$ notation was used for the ${ }^{15} \mathrm{~N} /{ }^{14} \mathrm{~N}$ ratio expression $\left(\delta^{15} \mathrm{~N}\right)$, but in this case the standard referred to $\mathrm{N}_{2}$ in air and the analytical precision was $0 \cdot 13 \%$.

\section{Oxygen isotope analyses}

The oxygen $(\mathrm{O})$ isotope composition $\left(\delta^{18} \mathrm{O}\right)$ was determined only in mature grain at the Scientific Facilities of the University of Barcelona. The ${ }^{18} \mathrm{O} /{ }^{16} \mathrm{O}$ ratios of dry plant samples were determined by an on-line pyrolysis technique using a thermo-chemical elemental analyser (TC/EA, Thermo Quest Finnigan, Bremen, Germany) coupled with an IRMS (Delta C Finnigan MAT, Bremen, Germany). Results were expressed as $\delta^{18} \mathrm{O}$ values using a secondary standard calibrated against the Vienna standard mean oceanic water (VSMOW), and the analytical precision was $0 \cdot 2 \%$.

$\delta^{18} \mathrm{O}(\% \mathrm{o})=\left[\left(\frac{R_{\text {sample }}}{R_{\text {Standard }}}\right)-1\right] \times 1000$

Spatial analysis and heritability

For each trial, raw data were adjusted for spatial trends using an automatic model selection based on Akaike's Information Criterion (AIC) and Schwarz's Bayesian Criterion (BIC) (Kehel et al. 2010). For each trial, the error model with the minimum value of $\mathrm{AIC}$ was then chosen as the best model for that trait in that trial. For the selected model, a generalized heritability $\left(h^{2}\right)$ coefficient for the test line effects (Cullis et al. 2006; Kelly et al. 2007) was then calculated from an analysis fitting the test lines as random as

$h^{2}=1-\frac{\operatorname{mean}(\text { pev })}{\sigma_{g}^{2}}$

where $\sigma_{g}^{2}$ was the estimated variance of the random test line effects and pev was the vector of estimated prediction error variances for the random test line using empirical best linear unbiased predictor (EBLUP). Both quantities were provided as a standard output from a mixed model in Genstat 12th edition (Payne et al. 2009).

\section{Genetic correlation}

For the genetic correlation between traits $\mathrm{A}$ and $\mathrm{B}$, the formula described by Falconer \& Mackay (1996) was used as follows:

$r_{\mathrm{g}}=\sigma_{\mathrm{AB}} /\left(\sigma_{\mathrm{A}} \times \sigma_{\mathrm{B}}\right)$

where $\sigma_{\mathrm{AB}}$ was the square root of genetic covariance between $\mathrm{A}$ and $\mathrm{B}, \sigma_{\mathrm{A}}$ was the square root of genetic 
Table 1a. Descriptive statistics under the two environmental conditions for the agronomical traits studied in a collection of 114 RIL of durum wheat. All statistics were calculated after data adjustment. Column P shows the probability relating to differences between the RF and IR environments. S.E.M.is the standard error of the mean of the 228 values

\begin{tabular}{|c|c|c|c|c|c|c|c|c|c|c|}
\hline \multicolumn{4}{|c|}{ Rainfed } & \multirow[b]{2}{*}{ Trait } & \multirow[b]{2}{*}{ S.E.M. } & \multirow[b]{2}{*}{$P$} & \multicolumn{4}{|c|}{ Irrigated } \\
\hline Size & Mean & Max & Min & & & & Size & Mean & Max & Min \\
\hline 114 & 228 & 360 & 125 & Biomass 3L (kg/ha) & $3 \cdot 5$ & $<0.001$ & 114 & 191 & 314 & 66 \\
\hline 114 & 1473 & 2321 & 766 & Biomass 6L (kg/ha) & $26 \cdot 6$ & NS & 114 & 1456 & 2849 & 384 \\
\hline 114 & 17034 & 27328 & 8928 & Biomass anthesis (kg/ha) & $259 \cdot 2$ & $<0.01$ & 114 & 15559 & 23344 & 5524 \\
\hline 114 & 14015 & 17318 & 10149 & Biomass maturity (kg/ha) & $156 \cdot 2$ & $<0.001$ & 114 & 16559 & 23001 & 11474 \\
\hline 114 & 3551 & 5541 & 2130 & GY (kg/ha) & $73 \cdot 9$ & $<0.001$ & 114 & 4617 & 9906 & 1827 \\
\hline 114 & $25 \cdot 2$ & $40 \cdot 5$ & $14 \cdot 1$ & Harvest Index & $0 \cdot 41$ & $<0.001$ & 114 & $29 \cdot 5$ & $45 \cdot 5$ & $7 \cdot 4$ \\
\hline 114 & 352 & 473 & 212 & Spikes/m² & $4 \cdot 4$ & $<0.001$ & 114 & 388 & 559 & 206 \\
\hline 114 & $32 \cdot 5$ & $58 \cdot 5$ & $19 \cdot 8$ & TGW (g) & $0 \cdot 61$ & $<0.001$ & 114 & $37 \cdot 7$ & $65 \cdot 7$ & $22 \cdot 7$ \\
\hline 114 & 11006 & 17544 & 5164 & Grains $/ \mathrm{m}^{2}$ & $153 \cdot 3$ & $<0.001$ & 114 & 12466 & 20835 & 5425 \\
\hline
\end{tabular}

NS: not significant.

variance of $\mathrm{A}$ and $\sigma_{\mathrm{B}}$ was the square root of genetic variance of $B$.

The square root of genetic covariance between $A$ and $\mathrm{B}$ was computed as

$\sigma_{\mathrm{A} . \mathrm{B}}=\left(\sigma_{(\mathrm{A}+\mathrm{B})}^{2}-\left(\sigma_{\mathrm{A}}^{2}+\sigma_{\mathrm{B}}^{2}\right)\right) / 2$

Means of adjusted data for each environment were compared by Duncan's test $(P<0 \cdot 05)$ or by the Tukey-b multiple comparison test $(P<0 \cdot 05)$. A bivariate correlation procedure was used to calculate the Pearson correlation coefficients. Multiple linear regression analysis (stepwise) was used to analyse the relationship between the studied variables. Linear stepwise models were built from water and genotype means. Data were analysed using the SPSS statistical package (SPSS Inc., Chicago, IL, USA).

\section{RESULTS}

Effect of water treatment on GY and total biomass

The water treatment significantly affected GY and biomass at maturity as well as $\mathrm{HI}$ (Table $1 a$ ). The IR treatment increased GY by 30\% compared with RF, while total aerial biomass at maturity and $\mathrm{HI}$ increased by 18 and $17 \%$, respectively. Biomass at the $3 \mathrm{~L}$ and $6 \mathrm{~L}$ stages and at anthesis was slightly higher for the RF treatment than for IR. The biomass was significantly higher under IR (18\%) only at maturity. The ranges of the different traits between the highest and lowest yielding genotypes were also largest for the IR treatment.
Effect of water treatment on $\delta^{13} \mathrm{C}, \delta^{18} \mathrm{O}, \delta^{15} \mathrm{~N}$ and $\mathrm{N}$ content

The $\delta^{13} \mathrm{C}$ of seedlings (6L stage) was not significantly different between treatments $(-29 \cdot 8 \%$ ) (Table $1 b$ ). Later, it became more positive as the crop developed, reaching $-23 \cdot 2 \%$ o $(\mathrm{RF})$ and $-23 \cdot 5 \%$ o $(\mathrm{IR})$ in the mature grain, a small but significant difference. The flag leaf blade at anthesis showed intermediate values ( $-26 \cdot 3 \%$ for RF and $-26 \cdot 7 \%$ or for IR) between the $6 \mathrm{~L}$ stage and the mature grain.

The $\delta^{18} \mathrm{O}$ was only measured in the mature grain, and it was found to be slightly higher under RF $(32 \cdot 6 \%)$ than under IR (32.3\%) conditions. The range of values was found to be larger under RF $(9 \cdot 2 \%)$ compared with IR $(7 \cdot 6 \%)$.

The $\delta^{15} \mathrm{~N}$ was always higher under IR conditions, regardless of the developmental stage at which it was measured. The higher difference $(1 \cdot 4 \%)$ between RF and IR was found in blades at anthesis and $\delta^{15} \mathrm{~N}$ of mature grain was significantly lower in $\operatorname{RF}(3.9 \%$ ) than in IR plants $(4 \cdot 6 \%)$.

Nitrogen concentration ( $\mathrm{g} \mathrm{N} / \mathrm{kg}$ dry matter (DM)) in seedlings was similar in both trials, while at anthesis values for the flag leaf were lower at RF $(34 \mathrm{~g} \mathrm{~N} / \mathrm{kg}$ ) compared with IR ( $37 \mathrm{~g} \mathrm{~N} / \mathrm{kg}$ ) but higher in grain at RF (36 g N/kg), compared with IR (32 g N/kg). The weight of the grains was negatively correlated with the concentration of $\mathrm{N}$ in grains, both under RF $(r=-0 \cdot 413$, $P<0 \cdot 01)$ and IR $(r=0.514, P<0 \cdot 01)$. Total $\mathrm{N}$ accumulated in the grains (obtained by multiplying GY by $N$ concentration in the grains) was lower under RF (116 kg N/ha) than under IR (146 kg N/ha). 
Table 1b. Descriptive statistics under the two environmental conditions for the stable isotope traits studied in a collection of 114 RIL of durum wheat. All statistics were calculated after data adjustment. Column P shows the probability relating to differences between the $R F$ and IR environments. S.E.M. is the standard error of the mean of the 228 values

\begin{tabular}{|c|c|c|c|c|c|c|c|c|c|c|}
\hline \multicolumn{4}{|c|}{ Rainfed } & \multirow[b]{2}{*}{ Trait } & \multirow[b]{2}{*}{ S.E.M. } & \multirow[b]{2}{*}{$P$} & \multicolumn{4}{|c|}{ Irrigated } \\
\hline Size & Mean & Max & Min & & & & Size & Mean & Max & Min \\
\hline 114 & $-29 \cdot 8$ & $-29 \cdot 0$ & $-30 \cdot 6$ & $\delta^{13} \mathrm{C} 6 \mathrm{~L}(\%)$ & $0 \cdot 02$ & NS & 114 & $-29 \cdot 8$ & $-29 \cdot 0$ & $-30 \cdot 5$ \\
\hline 114 & $-26 \cdot 3$ & $-24 \cdot 5$ & $-28 \cdot 1$ & $\delta^{13} \mathrm{C}$ flag leaf blade (\%o) & $0 \cdot 05$ & $<0 \cdot 001$ & 114 & $-26 \cdot 7$ & $-25 \cdot 2$ & $-28 \cdot 9$ \\
\hline 114 & $-23 \cdot 2$ & $-22 \cdot 3$ & $-24 \cdot 3$ & $\delta^{13} \mathrm{C}$ mature grain (\%o) & $0 \cdot 03$ & $<0 \cdot 001$ & 114 & $-23 \cdot 5$ & $-22 \cdot 5$ & $-24 \cdot 9$ \\
\hline 114 & 5 & 9 & 1 & $\delta^{15} \mathrm{~N} 6 \mathrm{~L}(\%)$ & $0 \cdot 1$ & $<0 \cdot 01$ & 114 & 6 & 9 & 3 \\
\hline 114 & 5 & 7 & 2 & $\delta^{15} \mathrm{~N}$ flag leaf blade (\%o) & $0 \cdot 1$ & $<0 \cdot 001$ & 114 & 6 & 12 & 2 \\
\hline 114 & 4 & 6 & 1 & $\delta^{15} \mathrm{~N}$ mature grain $(\% \mathrm{o})$ & $0 \cdot 1$ & $<0 \cdot 001$ & 114 & 5 & 8 & 2 \\
\hline 114 & $39 \cdot 0$ & 50 & 27 & $\mathrm{~N}$ concentration $6 \mathrm{~L}$ (g N/kg) & $0 \cdot 30$ & NS & 114 & $38 \cdot 2$ & 47 & 27 \\
\hline 114 & $33 \cdot 5$ & 42 & 23 & $\mathrm{~N}$ concentration flag leaf blade ( $\mathrm{g} \mathrm{N} / \mathrm{kg}$ ) & $0 \cdot 03$ & $<0 \cdot 001$ & 114 & $36 \cdot 7$ & 47 & 23 \\
\hline 114 & $36 \cdot 3$ & 45 & 21 & $\mathrm{~N}$ concentration mature grain $(\mathrm{g} \mathrm{N} / \mathrm{kg})$ & $0 \cdot 03$ & $<0 \cdot 001$ & 114 & $31 \cdot 7$ & 40 & 24 \\
\hline 114 & 33 & 37 & 28 & $\delta^{18} \mathrm{O}$ mature grain $(\%$ ) & $1 \cdot 2$ & $<0.05$ & 114 & 32 & 38 & 30 \\
\hline
\end{tabular}

NS: not significant.

Phenotypic variation in GY explained by agronomical and physiological traits

Pearson correlation coefficients between yield components and the $\delta^{13} \mathrm{C}$ of different stages were stronger, in general, under RF than under IR, with these coefficients increasing from earlier to later developmental stages (Table 2). Thus, the highest absolute values of these coefficients were always found for mature grain under both water conditions. The $\delta^{13} \mathrm{C}$ correlated negatively against GY and most of the yield components. The highest correlation coefficient between the $\delta^{13} \mathrm{C}$ of mature grain and any yield component was comparable with that of the $\delta^{13} \mathrm{C}$ of mature grain and GY $(-0.448$ and -0.402 for $R F$ and IR, respectively (Fig. 3, top).

The Pearson correlation coefficients between yield components and the $\delta^{15} \mathrm{~N}$ of different stages were generally weak or not significant. Only the $\delta^{15} \mathrm{~N}$ of mature grain was correlated with GY and TGW under both RF $(-0.354, P<0.01$ and $-0.411, P<0.01$, respectively) and IR $(-0.342, P<0.01$ and -0.235 , $P<0 \cdot 05$, respectively), and with spikes $/ \mathrm{m}^{2}$ under $I R$ $(-0 \cdot 354, P<0 \cdot 01)$ (Fig. 3, bottom).

There was no significant Pearson correlation coefficient for $\delta^{18} \mathrm{O}$ with any measured parameter under RF conditions, whereas under IR it was correlated $(r=0 \cdot 277, P<0 \cdot 01)$ with GY and with the $\delta^{13} \mathrm{C}$ of flag leaf blades $(r=0 \cdot 243, P<0 \cdot 01)$.

Common yield components such as TGW, number of spikes $/ \mathrm{m}^{2}$ or number of grains $/ \mathrm{m}^{2}$ were significantly correlated with GY under both treatments.
Heritabilities and genetic correlations of agronomic and physiological traits against GY

Broad sense heritabilities $\left(H^{2}\right)$ for biomasses of seedlings, GY and $\mathrm{HI}$ were higher under RF conditions than under IR (Table 3). In contrast, $H^{2}$ for biomass at maturity was lower under RF. Heritabilities for $\delta^{13} \mathrm{C}$ were always above $0 \cdot 60$, regardless of the plant part studied, and the values were quite similar between IR and RF trials. Heritabilities for $\delta^{15} \mathrm{~N}$ and $\mathrm{N}$ concentration were generally quite low, except for the flag leaf blade of IR at anthesis $(0 \cdot 71)$. Heritability for $\delta^{18} \mathrm{O}$ in grain was also very low, for both RF and IR trials.

While under RF conditions, none of the traits showed a higher $H^{2}$ than GY itself, under IR conditions $\delta^{13} \mathrm{C}$ measured at all three stages showed higher $H^{2}$ than GY. Heritabilities were also calculated for the different traits over environments. In these cases, only the $\delta^{13} \mathrm{C}$ of seedlings and $\mathrm{N}$ concentration flag leaf blades showed higher heritabilities than GY while the $H^{2}$ of $\delta^{18} \mathrm{O}$ was very low. In this regard, the heritability of grain number was intermediate $(0.59$ under RF and 0.37 under IR), whereas the heritability for number of spikes was very low under both environments. However, heritability for the grain size was very high (0.90 for RF and 0.87 for IR).

Genetic correlations (Table 3) with GY could not be calculated for a number of traits because of their very low heritability values. However, the genetic correlations for $\mathrm{HI}$ were maximum (1.00) under both water conditions. The second and third highest genetic correlations under RF were against $\delta^{15} \mathrm{~N}(-0.72)$ and 


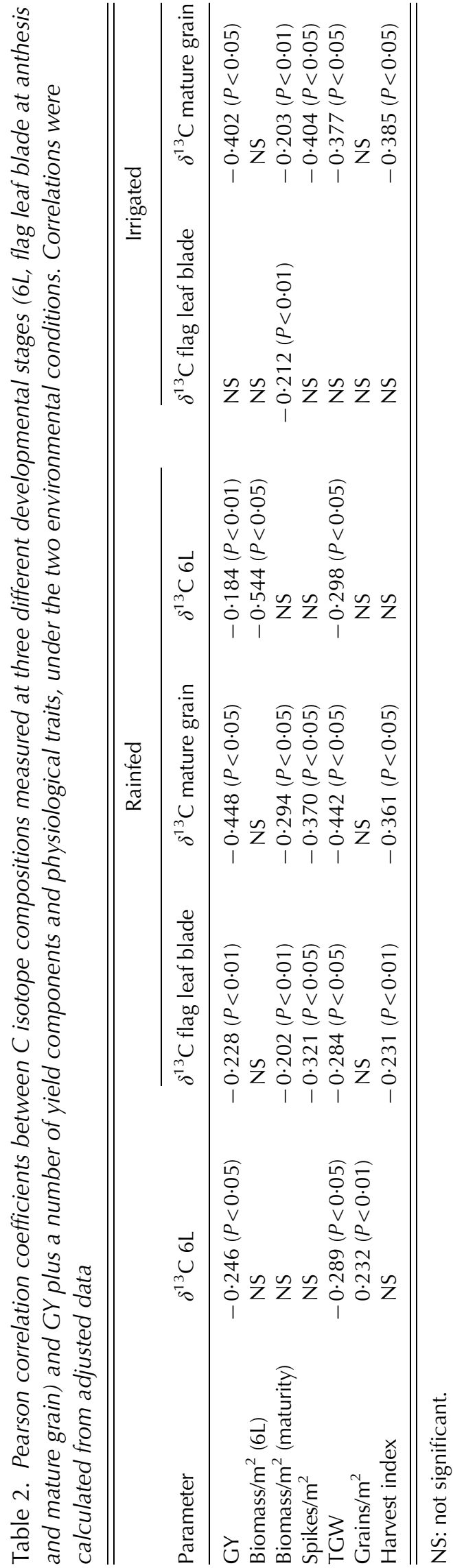

$\mathrm{N}$ concentration $(-0 \cdot 83)$ measured in mature grains. Under IR, seedling biomass $(+0 \cdot 64)$ and $\mathrm{N}$ concentration in flag leaf blades $(-0.63)$ showed the highest genetic correlations after that shown by the $\delta^{18} \mathrm{O}$ of mature grain $(+0.92)$. However, $\delta^{18} \mathrm{O}$ showed quite low heritability under both environments.

\section{Sources of variation in GY}

Within each water treatment, multiple linear regressions (Stepwise analysis) were performed using only stable isotopes $\left(\delta^{13} \mathrm{C}, \delta^{15} \mathrm{~N}\right)$ in the first instance and later accumulated biomasses and $\mathrm{N}$ concentration, measured in three different plant samples (whole seedlings, flag leaf blades and mature grain) as independent variables and with GY as a dependent variable. When only stable isotope compositions were supplied as independent variables (Table 4, top), the $\delta^{13} \mathrm{C}$ of mature grain alone accounted for 0.16 and $0 \cdot 20$ of the variation under IR and RF, respectively. The model also included the $\delta^{15} \mathrm{~N}$ of mature grain, thus explaining 0.24 and 0.26 of the variation under IR and $\mathrm{RF}$, respectively. It is worth mentioning that $\delta^{18} \mathrm{O}$ was chosen under $I R$, accounting for an increase in the variability explained from $0 \cdot 24$ to $0 \cdot 29$.

When, in addition to stable isotopes, $\mathrm{N}$ concentration and biomasses at different stages were also offered as independent variables (Table 4, bottom), the $\mathrm{N}$ concentration in the mature grain appeared as a second variable that described the variation in GY under RF, whereas the $\delta^{15} \mathrm{~N}$ of mature grain appeared as the third variable. The three variables accounted for up to 0.31 of the variation under RF. On the other hand, under IR, the $\delta^{13} \mathrm{C}$ of mature grain, biomass at maturity, the $\delta^{15} \mathrm{~N}$ of mature grains and the $\delta^{13} \mathrm{C}$ of flag leaf blades, entered in that order, accounted for up to 0.33 of GY variability. In a further step, $\delta^{18} \mathrm{O}$ was also included under IR, to account for up to 0.35 of GY variability although the $\delta^{13} \mathrm{C}$ for flag leaf blades disappeared from the model. In general, stable isotope signatures $\left(\delta^{13} \mathrm{C}, \delta^{15} \mathrm{~N}\right.$ and $\left.\delta^{18} \mathrm{O}\right)$, especially in the mature grain under IR, were able to explain some of the GY variability. However, some of the signatures appeared to be interchangeable. The first variable chosen was always $\delta^{13} \mathrm{C}$ for the mature grain. The additional isotope signatures added to the models were the $\delta^{15} \mathrm{~N}$ of mature grain, the $\delta^{13} \mathrm{C}$ of flag leaf blades or the $\delta^{18} \mathrm{O}$ of mature grain.

Further stepwise analysis was performed to understand the causes of variation in early vigour, measured as seedling biomass, and using $\delta^{13} \mathrm{C}, \quad \delta^{15} \mathrm{~N}$ and 


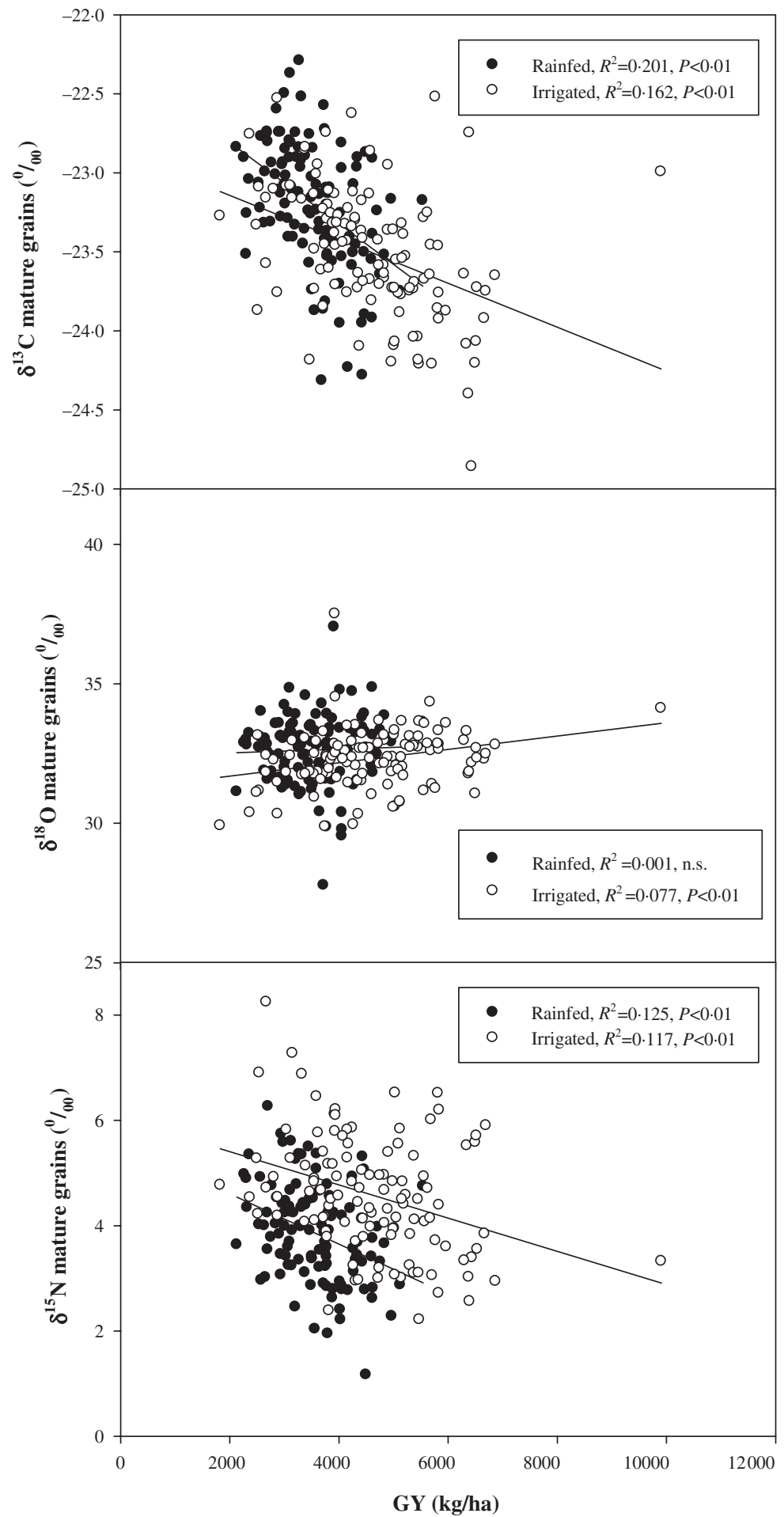

Fig. 3. Relationships across the 114 RILs between $\delta^{18} \mathrm{O}$ and $\delta^{15} \mathrm{~N}$ measured in mature grain and GY, under the two water treatments.

$\mathrm{N}$ concentration measured at different developmental stages as independent variables (Table 5). Under RF, the model only accommodated the $\delta^{13} \mathrm{C}$ of seedlings, accounting for $0 \cdot 18$ of the variation. Under IR, the $\delta^{13} \mathrm{C}$ of seedlings accounted for $0 \cdot 31$, whereas the addition of $\mathrm{N}$ concentration of seedlings increased the variation explained up to $0 \cdot 35$. Stable isotope signatures of later developed organs did not enter the stepwise models. 
Table 3. Heritabilities and genetic correlations under the two environmental conditions for the main traits studied: grain yield, biomass and harvest index, and isotope compositions for the different developmental stages. Heritabilties and genetic correlations were calculated from adjusted data

\begin{tabular}{|c|c|c|c|c|c|c|}
\hline \multirow[b]{2}{*}{ Parameter } & \multicolumn{3}{|c|}{ Heritabilities } & \multicolumn{3}{|c|}{ Genetic correlations } \\
\hline & Rainfed & Irrigated & $\begin{array}{l}\text { Over } \\
\text { environments }\end{array}$ & Rainfed & Irrigated & $\begin{array}{l}\text { Over } \\
\text { environments }\end{array}$ \\
\hline Grain yield & $0 \cdot 83$ & $0 \cdot 58$ & $0 \cdot 86$ & - & - & - \\
\hline Biomass $/ \mathrm{m}^{2}(6 \mathrm{~L})$ & $0 \cdot 75$ & $0 \cdot 18$ & $0 \cdot 36$ & $0 \cdot 09$ & $0 \cdot 64$ & $0 \cdot 37$ \\
\hline Biomass $/ \mathrm{m}^{2}$ (anthesis) & $0 \cdot 06$ & $0 \cdot 32$ & $0 \cdot 38$ & $0 \cdot 60$ & $0 \cdot 48$ & $0 \cdot 56$ \\
\hline Biomass $/ \mathrm{m}^{2}$ (maturity) & $0 \cdot 04$ & $0 \cdot 00$ & $0 \cdot 00$ & NA & NA & NA \\
\hline Harvest index & $0 \cdot 50$ & $0 \cdot 34$ & $0 \cdot 79$ & $1 \cdot 00$ & $1 \cdot 00$ & $1 \cdot 00$ \\
\hline$\delta^{13} \mathrm{C} 6 \mathrm{~L}$ & $0 \cdot 72$ & $0 \cdot 60$ & 0.97 & $-0 \cdot 17$ & $-0 \cdot 04$ & -0.33 \\
\hline$\delta^{13} \mathrm{C}$ flag leaf blade & $0 \cdot 68$ & $0 \cdot 79$ & $0 \cdot 35$ & -0.47 & $0 \cdot 19$ & -0.83 \\
\hline$\delta^{13} \mathrm{C}$ mature grain & $0 \cdot 64$ & $0 \cdot 61$ & $0 \cdot 72$ & -0.55 & $-0 \cdot 35$ & $-0 \cdot 83$ \\
\hline$\delta^{15} \mathrm{~N} 6 \mathrm{~L}$ & $0 \cdot 00$ & $0 \cdot 00$ & $0 \cdot 01$ & NA & NA & $1 \cdot 00$ \\
\hline$\delta^{15} \mathrm{~N}$ flag leaf blade & $0 \cdot 00$ & $0 \cdot 52$ & $0 \cdot 30$ & NA & $-0 \cdot 32$ & $-0.25 \mathrm{~ns}$ \\
\hline$\delta^{15} \mathrm{~N}$ mature grain & $0 \cdot 19$ & $0 \cdot 00$ & $0 \cdot 68$ & $-0 \cdot 72$ & NA & $-0 \cdot 72$ \\
\hline $\mathrm{N}$ concentration $6 \mathrm{~L}$ & $0 \cdot 22$ & $0 \cdot 00$ & $0 \cdot 00$ & $0 \cdot 06$ & NA & $1 \cdot 00$ \\
\hline $\mathrm{N}$ concentration flag leaf blade & $0 \cdot 12$ & $0 \cdot 71$ & 0.93 & NA & -0.63 & -0.53 \\
\hline $\mathrm{N}$ concentration mature grain & $0 \cdot 32$ & $0 \cdot 00$ & $0 \cdot 70$ & $-0 \cdot 83$ & NA & -0.67 \\
\hline$\delta^{18} \mathrm{O}$ mature grain & $0 \cdot 26$ & $0 \cdot 27$ & $0 \cdot 01$ & 0.08 & $0 \cdot 92$ & $1 \cdot 00$ \\
\hline
\end{tabular}

NA: not available.

Table 4. Stepwise analysis explaining $G Y$ variation from $\delta^{13} C, \delta^{15} N, \delta^{18} O, N$ concentration and accumulated biomass on three different developmental stages. Top: only $\delta^{13} \mathrm{C}$ and $\delta^{15} \mathrm{~N}$ were used in the models. Bottom: $\delta^{13} \mathrm{C}, \delta^{15} \mathrm{~N}, \mathrm{~N}$ concentration and biomass were used in the models

\begin{tabular}{|c|c|c|c|c|c|c|c|}
\hline \multicolumn{3}{|c|}{ Water treatment $\quad$ Variable/s chosen } & $r$ & $R^{2}$ & \multicolumn{2}{|c|}{$\Delta R^{2}$} & $P$ \\
\hline \multicolumn{4}{|c|}{ Adjusted data without controls (114 RILs) } & \multicolumn{4}{|c|}{ Biomass not offered } \\
\hline \multicolumn{2}{|c|}{ Rainfed } & $\begin{array}{l}\delta^{13} \mathrm{C} \text { grain }(-) \\
\delta^{13} \mathrm{C} \text { grain }(-), \delta^{15} \mathrm{~N} \text { grain }(-)\end{array}$ & $\begin{array}{l}0 \cdot 448 \\
0 \cdot 510\end{array}$ & $\begin{array}{l}0 \cdot 201 \\
0 \cdot 260\end{array}$ & \multicolumn{2}{|c|}{$\begin{array}{l}0 \cdot 201 \\
0 \cdot 059\end{array}$} & $\begin{array}{l}<0 \cdot 001 \\
<0 \cdot 01\end{array}$ \\
\hline \multicolumn{2}{|l|}{ Irrigated } & $\begin{array}{l}\delta^{13} \mathrm{C} \text { grain }(-) \\
\delta^{13} \mathrm{C} \text { grain }(-), \delta^{15} \mathrm{~N} \text { grain }(-) \\
\delta^{13} \mathrm{C} \text { grain }(-), \delta^{15} \mathrm{~N} \text { grain }(-), \delta^{18} \mathrm{O} \text { grain }\end{array}$ & $\begin{array}{l}0 \cdot 402 \\
0 \cdot 489 \\
0 \cdot 540\end{array}$ & $\begin{array}{l}0 \cdot 162 \\
0 \cdot 239 \\
0 \cdot 292\end{array}$ & \multicolumn{2}{|c|}{$\begin{array}{l}0 \cdot 162 \\
0 \cdot 077 \\
0 \cdot 053\end{array}$} & $\begin{array}{l}<0 \cdot 001 \\
<0 \cdot 001 \\
<0 \cdot 01\end{array}$ \\
\hline \multicolumn{4}{|c|}{ Adjusted data without controls (114 RILs) } & \multicolumn{4}{|c|}{ When biomass was offered* } \\
\hline RF & $\begin{array}{l}\delta^{13} \mathrm{C} \\
\delta^{13} \mathrm{C} \\
\delta^{13} \mathrm{C}\end{array}$ & $\begin{array}{l}(-) \\
(-), \mathrm{N} \text { concentration grain }(-) \\
(-), \mathrm{N} \text { concentration grain }(-), \delta^{15} \mathrm{~N} \text { grain }\end{array}$ & & $\begin{array}{l}0 \cdot 448 \\
0 \cdot 510 \\
0 \cdot 559\end{array}$ & $\begin{array}{l}0 \cdot 201 \\
0 \cdot 260 \\
0 \cdot 312\end{array}$ & $\begin{array}{l}0 \cdot 201 \\
0 \cdot 059 \\
0 \cdot 052\end{array}$ & $\begin{array}{l}<0 \cdot 001 \\
<0 \cdot 01 \\
<0 \cdot 01\end{array}$ \\
\hline Irrigated & $\begin{array}{l}\delta^{13} \mathrm{C} \\
\delta^{13} \mathrm{C} \\
\delta^{13} \mathrm{C} \\
\delta^{13} \mathrm{C} \\
\delta^{13} \mathrm{C}\end{array}$ & $\begin{array}{l}(-) \\
(-), \text { biomass maturity }(+) \\
(-), \text { biomass maturity }(+), \delta^{15} \mathrm{~N} \text { grain }(-) \\
(-) \text {, biomass maturity }(+), \delta^{15} \mathrm{~N} \text { grain }(-), \delta \\
(-), \text { biomass maturity }(+), \delta^{15} \mathrm{~N} \text { grain }(-), \delta\end{array}$ & $\begin{array}{l}\text { leaf }(+) \\
n(+)\end{array}$ & $\begin{array}{l}0 \cdot 402 \\
0 \cdot 489 \\
0 \cdot 549 \\
0 \cdot 574 \\
0 \cdot 593\end{array}$ & $\begin{array}{l}0 \cdot 162 \\
0 \cdot 239 \\
0 \cdot 302 \\
0 \cdot 329 \\
0 \cdot 352\end{array}$ & $\begin{array}{l}0 \cdot 162 \\
0 \cdot 077 \\
0 \cdot 063 \\
0 \cdot 027 \\
0 \cdot 050\end{array}$ & $\begin{array}{l}<0 \cdot 001 \\
<0 \cdot 001 \\
<0 \cdot 01 \\
<0 \cdot 05 \\
<0 \cdot 01\end{array}$ \\
\hline
\end{tabular}

* Biomass at $3 \mathrm{~L}, 6 \mathrm{~L}$, anthesis and maturity.

\section{DISCUSSION}

Growth conditions and biomass accumulation

Water stress associated with RF conditions reduced GY by $23 \%$ when compared with the IR treatment.
However, the yields of the IR trial were 25 and 35\% lower than that achieved under IR for the same wheat population during the following two seasons (2006 and 2007), which produced mean yields of 6199 and $7122 \mathrm{~kg} / \mathrm{ha}$, respectively (Kehel et al. 2010). This is 
Table 5. Stepwise analysis explaining early vigour (biomass at $6 L$ ) variation from $\delta^{13} \mathrm{C}, \delta^{15} \mathrm{~N}$ and $\mathrm{N}$ concentration measured at three development stages

\begin{tabular}{|c|c|c|c|c|c|}
\hline Water treatment & Variable/s chosen & $r$ & $R^{2}$ & $\Delta R^{2}$ & $P$ \\
\hline \multicolumn{6}{|c|}{ Adjusted data without checks (114 RILs) } \\
\hline Rainfed & $\delta^{13} \mathrm{C}$ seedling $(-)$ & 0.422 & $0 \cdot 178$ & $0 \cdot 178$ & $<0.001$ \\
\hline Irrigated & $\begin{array}{l}\delta^{13} \mathrm{C} \text { seedling }(-) \\
\delta^{13} \mathrm{C} \text { seedling }(-), \mathrm{N} \text { concentration } \\
\text { seedling }(+)\end{array}$ & $\begin{array}{l}0.554 \\
0.591\end{array}$ & $\begin{array}{l}0 \cdot 307 \\
0 \cdot 350\end{array}$ & $\begin{array}{l}0 \cdot 307 \\
0 \cdot 040\end{array}$ & $\begin{array}{l}<0.001 \\
<0.01\end{array}$ \\
\hline
\end{tabular}

well within the yield achieved in the same region of Tunisia with the widely used cultivar Karim (LatiriSouki et al. 1998) as well as in other Mediterranean locations under full IR (Merah et al. 2001a; Garcia del Moral et al. 2003; Maccaferri et al. 2010). The 2005 RF and IR trials experienced moderate and mild stress conditions, respectively. The differences in water availability between the RF and the IR trials increased progressively throughout the crop cycle. Although drought and differences in water supply started very early, differences in biomass were still not significant at the $6 \mathrm{~L}$ stage (seedlings). Differences in biomass reached significance later in development, at anthesis, and further increased at maturity.

Isotope signatures throughout the growth stages

Carbon isotope composition was used to assess water status throughout the crop cycle, by measuring it in samples from vegetative and reproductive phases of the crop. When measured in plant matter, $\delta^{13} \mathrm{C}$ provides a time-integrated measurement of TE (the ratio of $\mathrm{C}$ gained to water transpired) over the period during which dry matter is assimilated (Farquhar \& Richards 1984). In this regard, according to $\delta^{13} \mathrm{C}$, TE was higher under RF compared with IR in the later stages of crop growth (anthesis and maturity), but not in early seedling growth. This pattern agrees with an increasing difference in water status between RF and IR plants during the season. The higher water availability under IR would have allowed the maintenance of higher transpiration rates during the whole growth cycle, but with lower efficiencies (Farquhar \& Richards 1984; Hubick \& Farquhar 1989) following a progressive increase in water deficit conditions. The anatomy of the photosynthetic organs may also be involved, with upper photosynthetic organs being adapted to the progressively higher radiation and transpirative gradients achieved during the growing season (Araus et al. 1989). In this sense, although the spike is formed at earlier stages, it is a basic contributor of assimilates for the growing grains and has an intrinsically high $\delta^{13} \mathrm{C}$ value (Bort et al. 1998) associated with the specific xeromorphic characteristics of this organ (Tambussi et al. 2005a, 2007).

In addition to $\delta^{13} \mathrm{C}$ becoming more positive, in later stages the range of genotypic variability in $\delta^{13} \mathrm{C}$ values steadily increased from the seedling $(1.6$ and $1.5 \%$ for RF and IR, respectively) to the mature grain (2.0 and $2.4 \%$ for $R F$ and IR, respectively). This might be related to differential adaptation/ responses of the different RILs to the progressively changing environmental conditions in terms of increasing VPD.

Similar trends have been found for stable isotope composition of $\mathrm{N}$. Natural variation in plant $\mathrm{N}$ isotope composition $\left(\delta^{15} \mathrm{~N}\right)$ has been proposed as a useful trait for screening, as it is linked to plant $\mathrm{N}$ metabolism. No clear relationship between $\delta^{15} \mathrm{~N}$ and biomass and/or GY has been previously reported (Ellis et al. 1997, 2002; Handley et al. 1997), despite the fact that $\delta^{15} \mathrm{~N}$ has been used to map the phenotype of populations exposed to salinity (Ellis et al. 2002; Yousfi et al. 2009). In the present study, the results of $\delta^{15} \mathrm{~N}$ follow the expected trend of lower values under stress conditions compared with favourable conditions, which can be explained by a reduced stomatal conductance, whose effect is a reduction in the loss of ammonia and nitrous oxide that would then reduce ${ }^{15} \mathrm{~N}$ enrichment, hence decreasing $\delta^{15} \mathrm{~N}$ (Farquhar et al. 1980; Smart \& Bloom 2001). In the present study, the difference in $\delta^{15} \mathrm{~N}$ between RF and IR increased from the vegetative stage to the final mature grain. Raimanová \& Haberle (2010) reported a decrease in grain $\delta^{15} \mathrm{~N}$ in fertilized wheat as a consequence of water stress. The greater reduction in grain $\delta^{15} \mathrm{~N}$ under water shortage could be the result of a lower demand for $\mathrm{N}$. Thus, a greater proportion of grain $\mathrm{N}$ originating from $\mathrm{N}$ fertilizer (ammonium nitrate) compared with the soil $\mathrm{N}$ coming from nitrification of organic matter, which is characterized 
by a higher $\delta^{15} \mathrm{~N}$ (Serret et al. 2008), may have resulted in a lower $\delta^{15} \mathrm{~N}$ of grains in the less productive trial. While $\delta^{15} \mathrm{~N}$ decreased as plant parts were sampled later in the crop cycle, the values were always higher under IR compared with RF for the three plant parts, which would be consistent with the higher amount of $\mathrm{N}$ accumulated in grains under IR.

The signature of the stable oxygen isotope $\left(\delta^{18} \mathrm{O}\right)$ in plant matter has been reported as reflecting the transpirative (Barbour 2007; Farquhar et al. 2007) conditions (i.e. evaporative enrichment of leaf water caused by transpiration) in which the plants were grown. Accordingly, Barbour et al. (2000a) proposed the use of $\delta^{18} \mathrm{O}$ in plant matter as an integrative indicator of genetic differences in stomatal conductance for bread wheat, and its application to drought conditions has been assessed in further studies (Ferrio et al. 2007; Cabrera-Bosquet et al. 2009, 2011). Condon (2012) recently suggested that variation in oxygen isotope composition $\left(\delta^{18} \mathrm{O}\right)$ is more strongly related to variation in stomatal conductance than is variation of $\delta^{13} \mathrm{C}$, and therefore may provide stronger relationships with water extraction. The $\delta^{18} \mathrm{O}$ is expected to increase with higher evaporative demand and lower stomatal conductance, as is the case in winter cereals under terminal drought. The results shown in the present work confirm this trend since the $\delta^{18} \mathrm{O}$ of mature grains was slightly lower under IR conditions compared witho RF. The difference between the two treatments was minimal but significant. The range of variation in $\delta^{18} \mathrm{O}$ was larger for $\mathrm{RF}(9 \cdot 2 \%$ ) than for IR $(7 \cdot 6 \%)$, probably expressing larger adaptive genotypic variability to adverse environmental conditions. Recently, no water treatment differences were observed in wheat for grain $\delta^{18} \mathrm{O}$ (Condon 2012), probably because the water availability was not different enough between the two treatments imposed after anthesis.

When water is limiting crop production, conservation and efficient use of water are very important considerations for agriculture (Blum 2009) when aiming to increase GY. The larger relative amount of water used by the IR treatment to obtain an increase in dry matter production resulted in a lower WUE for IR compared with the RF treatment, as also reported when selection for high TE favoured genotypes with low production under water deficit, since high $\Delta^{13} \mathrm{C}$ has frequently been found to be associated with high GY (Acevedo 1993; Ehdaie \& Waines 1993; Morgan et al. 1993; Sayre et al. 1995; Araus et al. 1997, 1998; Merah et al. 1999).
Heritabilities for $\delta^{15} \mathrm{~N}$ and $\delta^{18} \mathrm{O}$, together with those of biomass and the yield components measured in the present work, were lower than for GY, both when these $\mathrm{H}^{2}$ were measured for each water condition and when they were calculated over growing conditions. Only $\delta^{13} \mathrm{C}$ for the three stages and under both water treatments showed consistently higher $H^{2}$ than GY, which supports the potential usefulness of the signature of this stable isotope in breeding programmes. In addition, $\mathrm{N}$ concentration of the flag leaf blade under IR also showed a relatively high heritability. It is worth mentioning that the largest $H^{2}$ obtained was that of $\delta^{13} \mathrm{C}$ measured in seedlings over the two environments. Thus, at this early stage of the crop, $\delta^{13} \mathrm{C}$ appears as a constitutive trait independent of environment as previously emphasized by Condon \& Richards (1992) and Rebetzke et al. (2002), which also explains the highest heritabilities for $\delta^{13} \mathrm{C}$ being found in seedlings.

Among the isotopes studied in the present work, $\delta^{13} \mathrm{C}$ was the best correlated with $\mathrm{GY}$, whereas $\delta^{15} \mathrm{~N}$ and $\delta^{18} \mathrm{O}$, as well as other plant traits such as the amount of biomass at the seedling stage and anthesis, showed lower genetic correlations with GY. In this regard, CSIRO in Australia have developed and released several commercial wheat cultivars (Condon et al. 2004) using low $\Delta^{13} \mathrm{C}$ (and thus high TE) measured at tillering under favourable conditions as the selection criterion (Richards 2006) based on the relationship that has been postulated for this trait. These varieties are adapted to severe water stress conditions and rely solely upon soil moisture accumulated before planting. However, it is shown in the present paper that the relationship between $\delta^{13} \mathrm{C}$ and final GY in the early stages of crop growth is the reverse: i.e. lower TE is related to a higher GY. However, this lower efficiency has a relatively low effect on genotypic variability of GY (see later). This might be related to the 'efficient use of water' described by Blum (2009), which limits photosynthesis, as opposed to ' $W U E^{\prime}$. On the other hand, the genetic correlations between the set of traits measured and GY showed a wide variability. However, it should be noted that some of the largest genetic correlations with GY were those shown by the $\delta^{13} \mathrm{C}$ of the flag leaf blades and mature grains when the combined effect of the two environments was considered, which would suggest that these parameters show some constitutive pattern. However, the same genetic correlations within each water treatment were considerably lower. In addition, Araus et al. (2003) 
showed stronger correlations, always positive, between $\mathrm{GY}$ and $\Delta{ }^{13} \mathrm{C}$ when it was measured in the mature grain than when it was measured in seedlings. In fact, when considering $\Delta^{13} \mathrm{C}$ in the seedlings, some relationships were negative and less significant, meaning that TE at the vegetative stage did not impact on GY. Breeding for transpiration-use efficiency under moderate stress has been considered a main target for a number of years, although recently, it appears that breeding for improvement of intrinsic photosynthetic capacity under favourable conditions would be the next step to be targeted (Foulkes et al. 2011; Parry et al. 2011; Reynolds et al. 2011).

As mentioned previously, the $H^{2}$ for $\delta^{18} \mathrm{O}$ in mature grain were quite low under the two environments and disappeared when data from the two conditions were combined. In contrast, the $H^{2}$ for $\delta^{15} \mathrm{~N}$ increased from the vegetative to the reproductive stages, when considering the combination of data from the two environments. In this case, $\delta^{15} \mathrm{~N}$ in the mature grains showed a relatively high heritability of 0.68 . Consequently, $\delta^{15} \mathrm{~N}$ seems to be a much more constitutive trait than $\delta^{18} \mathrm{O}$, and thus the former might have greater breeding potential than the latter. The low heritability of a trait can be due to a high genotype by environment interaction as well as a low genotypic effect compared with that of the environment. Information about heritability values for $\delta^{18} \mathrm{O}$ is scarce but they are generally thought to be lower than those for $\delta^{13}$ C. Even so, Ferrio et al. (2007) reported $\mathrm{H}^{2}$ values for $\delta^{18} \mathrm{O}$ in bread wheat that were higher than those for GY. Estimations of $\mathrm{H}^{2}$ values for $\delta^{18} \mathrm{O}$ in maize (L. Cabrera-Bosquet, unpublished results) give medium-high values, comparable with those for GY.

\section{Sources of variation of early vigour}

The causes of variation in early vigour were also assessed through multiple stepwise linear analyses of isotope signatures at seedling stages $v s$. biomass of seedlings at the $6 \mathrm{~L}$ stage. The $\delta^{13} \mathrm{C}$ was always the first parameter to be included in the models, whereas the second and subsequent parameters depended on the water conditions and whether biomass was excluded or not. The mechanisms responsible for genotypic differences in early vigour are of great interest for developing new genotypes adapted to water-limited situations. In contrast, in environments with typical Mediterranean climates (winter-spring rainfall), improved WUE did not confer an advantage in yield (Condon et al. 2004). In this case, early vigour seems to be more important (Tambussi et al. 2007) through its effect on improved light interception and a reduction in direct water evaporation from the soil. In the present work, it was only under IR that the $\mathrm{N}$ content of seedlings positively affected early vigour. This was probably related to a larger leaf area index (LAI), which appeared as the second parameter in a stepwise model explaining the variation of biomass accumulation in seedlings. Exhaustive screening of international wheat collections and a broad-based composite cross population has revealed several important sources of genetic variation for early plant vigour (Richards \& Lukacs 2002). As an example, Maydup et al. (2012) recently described that the use of semi-dwarf genotypes of wheat has decreased early vigour of modern cultivars.

In the present work, a negative correlation was found between $\delta^{13} \mathrm{C}$ and biomass at the seedling stage only for IR and not for RF. However, the stepwise model included the $\delta^{13} \mathrm{C}$ of seedlings as the first parameter, which explained some variation under both RF and IR. Furthermore, under IR, N content was included as a second parameter that explained the variation of seedling biomass. Under IR a higher WUE negatively affected seedling growth and thus early vigour. The negative sign of $\delta^{13} \mathrm{C}$ in both stepwise models means that a higher WUE impairs seedling growth. On the other hand, the positive sign on $\mathrm{N}$ content in the model for IR might mean that $N$ improved the WUE of seedlings.

The stepwise model at the seedling stage also included $\mathrm{N}$ concentration as the second parameter explaining variation in biomass, but only for the IR treatment. This might reflect differences in the thickness or density of the leaves, or the enhanced ability provided by the wettest environment to capture $\mathrm{N}$ available in the soil. This could be due to both water treatments being supplied with the same amount of $\mathrm{N}$ split into two applications, with the first just after the $3 \mathrm{~L}$ stage and the second just after the $5 \mathrm{~L}$ stage. A number of parameters showed that the RF trial suffered a mild stress during the growing season. The IR provided could support some recovery in the performance of the crop and increase dry matter accumulation in the form of total biomass and grain weight. Early vigour, although showing some correlation with GY, does not appear to be relevant in explaining performance of these genotypes under the environmental conditions studied. However, transpiration in the flag leaf had a minor effect on final GY under IR but not under RF conditions. The $\delta^{13} \mathrm{C}$ measured in different stages of 
the crop is able to explain a certain amount of variation in GY, as will be discussed in the next section.

A negative relationship between the leaf area and photosynthetic rate has been reported for wheat (Austin 1999). This negative correlation has been attributed to an increase in leaf thickness and/or tighter packing of mesophyll cells (even without an increase in leaf thickness) with higher $\mathrm{N}$ content and higher photosynthetic capacity in smaller leaves (Araus et al. 1986). Therefore, differences in photosynthetic rate seem to be due to the packing of mesophyll cells rather than to leaf thickness. The positive relationship between $\delta^{13} \mathrm{C}$ at $6 \mathrm{~L}$ stage and the chlorophyll content (data not shown) can be accounted for by the anatomy of the leaves. Higher leaf chlorophyll content during the vegetative stage might indicate a thicker or more compacted mesophyll cells that would decrease the $\mathrm{Ci} / \mathrm{Ca}$ by restriction of mesophyll conductance (Parry et al. 2011), thus making $\delta^{13} \mathrm{C}$ more positive. Indirectly, thicker leaves might produce a lower leaf area and reduce the total plant area.

\section{Sources of genotypic variation of GY}

Sources of variation of GY have been described by Evans et al. (1975), Slafer et al. (1999), Passioura (2002), Fischer (2007) and Reynolds et al. (2009). The importance of the different sources of variation in explaining GY was studied among a number of yield components and several agronomical and physiological parameters measured during the crop cycle. Under $\mathrm{RF}$, the negative and significant correlations found between $\delta^{13} \mathrm{C}$ at all stages and $\mathrm{GY}$ suggest that the higher yielding genotypes were those showing lower transpiration efficiencies. The same correlation coefficients were lower under IR compared with RF, and even the relationship with irrigated flag leaf blades was not significant. The negative relationship between GY and $\delta^{13} \mathrm{C}$ under both environments further supports the hypothesis that the RF trial was not under severe stress. A number of other yield components showed some significant correlations with $\delta^{13} \mathrm{C}$ at the different stages, especially under RF conditions, but these were lower or absent under IR. Total accumulated biomass at maturity, the number of spikes $/ \mathrm{m}^{2}$ and TGW showed negative correlations with $\delta^{13} \mathrm{C}$ especially when measured in flag leaves and mature grain under RF conditions, but only in the mature grain for IR. This suggests that lower TE occurred under both water conditions and that it enhanced the performance of these yield components. Under both water treatments, a larger use of water (although with less efficiency) enhanced dry matter accumulation through better photosynthetic performance (Blum 2009). In addition, tillering capacity (assessed through spikes $/ \mathrm{m}^{2}$ ) was not affected by differences in TE at the vegetative stage, whereas the filling and sink strength (Reynolds et al. 2004) of spikes and their previously formed grains were more dependent on the maintenance of transpiration by the flag leaf under RF than under IR, which finally improved the individual grain weight.

For Mediterranean environments, $\Delta{ }^{13} \mathrm{C}$ (particularly when measured in mature grains) is often positively correlated with GY (Araus et al. 1998, 2003; Villegas et al. 2000; Condon et al. 2004), but $\Delta{ }^{13} C$ in the flag leaf blade is also correlated with GY (Araus et al. 1998; Merah et al. 2001b). One of the reasons for this positive relationship is that a genotype exhibiting higher $\Delta^{13} \mathrm{C}$ shows greater capacity to maintain a better water status and thus more open stomata (see Araus et al. 2002; Condon et al. 2004) through most of the growth cycle. Blum (2009) has recently established that $\Delta^{13} \mathrm{C}$ is in fact an expression of the effective use of water (EUW) by the crop instead of the overall WUE. $\mathrm{He}$ also discusses that it is not a coincidence that EUW is an inverse acronym of WUE because very often high WUE is achieved at the expense of EUW.

The present work shows similar relationships to those reported by Ferrio et al. (2007) in wheat, between GY and $\delta^{13} \mathrm{C}$ (negative) and between GY and $\delta^{18} \mathrm{O}$ (positive, but significant only under IR). Although Ferrio et al. (2007) reported relatively poor correlations between $\delta^{13} \mathrm{C}$ and $\delta^{18} \mathrm{O}$, these parameters were not correlated at all in the current work. This would mean that the source of variation of GY related to $\delta^{13} \mathrm{C}$ is different and independent from the variation of $\mathrm{GY}$ related to $\delta^{18} \mathrm{O}$. Following the model discussed by Ferrio et al. (2007), the effect of evaporative demand or stomatal conductance is much more important under IR than under the RF conditions reported in the present paper. It is still unclear whether organic material formed in the leaf reflects either enrichment of water at the sites of evaporation within the leaf or the measured enrichment of leaf water as a whole (Barbour et al. 2000a). Cernusak et al. (2003) also found that enrichment of lamina leaf water was associated with primary veins compared with source water (i.e. there is a fractionation effect prior to evaporation in the leaf), and depleted compared with evaporative site water. In addition, water exported in phloem sap from photosynthesizing leaves was enriched compared with source water (Cernusak 
et al. 2003). This might explain the lack of a consistent relationship between $\delta^{18} \mathrm{O}$ and $\mathrm{GY}$ as well as its low heritability compared, for example, with $\delta^{13} \mathrm{C}$, in addition to the effects of retranslocation of assimilates reported by Condon (2012).

The $\delta^{13} \mathrm{C}$ of mature grain was always the first parameter that appeared in multiple stepwise linear regressions explaining the variation in GY in terms of a number of secondary traits. If the biomasses accumulated at different stages were removed from the model, the second parameter selected after $\delta^{13} \mathrm{C}$ was the $\delta^{15} \mathrm{~N}$ of mature grain. However, when the biomass was included, the second choice parameter was $\mathrm{N}$ concentration in mature grains under RF, and the biomass at maturity under IR. Both $\delta^{15} \mathrm{~N}$ and $\mathrm{N}$ concentration for RF, and $\delta^{15} \mathrm{~N}$ and biomass at maturity for $I R$, accounted for the same amount of variation in GY. What is remarkable is that both pairs describe different sources of variation, since one does not reject the other, and together with $\delta^{13} \mathrm{C}$ they account for $>0 \cdot 31$ of GY variation under RF and $>0 \cdot 35$ under IR.

The $\delta^{15} \mathrm{~N}$ always appeared in the stepwise models with a negative sign, which indicates that the more stressed genotypes were those showing a higher GY, in agreement with observations reported here for $\delta^{13} \mathrm{C}$ (less negative meaning more stressed). Robinson et al. (2000) found similar relationships and concluded that the most productive and stress tolerant genotypes were those that probably retained most $\mathrm{N}$, and therefore, they had the lowest plant $\delta^{15} \mathrm{~N}$. Conversely, genotypes expressing the least discrimination against ${ }^{15} \mathrm{~N}$ grew less and contained less $\mathrm{N}$. In the present work, the relationship between $\delta^{15} \mathrm{~N}$ and $\mathrm{N}$ concentration was not significant in mature grain.

The $\delta^{18} \mathrm{O}$ measured in mature grain appeared in the stepwise models only under IR conditions, but as a later choice, and this might indicate differential rates of assimilate remobilization to the filling grain between the two treatments (Condon 2012). Alternatively, it might be related to the fact that a wetter environment may be better for the expression/regulation of genotypic differences in stomatal conductance and/or temperature regulation between genotypes (Barbour et al. 2000a; Araus et al. 2003).

Finally, differences in early vigour (assessed as biomass at $3 \mathrm{~L}$ or $6 \mathrm{~L}$ ) were not related to any yield component (not even total number of grains) or to the final GY. Several authors have discussed the apparent discrepancies between early vigour and final performance of the crop. Botwright et al. (2002) concluded that there was potential to increase the yield of wheat by selecting for greater early vigour in a wheat breeding programme, and that the expression of vigour in field conditions and the translation of this improvement to higher yields were, however, dependent on the environment. Moreover, as discussed by Bort et al. (1998) for barley, the comparison of some parameters such as the performance of seedlings (affected by low temperatures) and GY (affected by terminal drought and higher temperatures), which are far apart in terms of the phenology of the crop, may explain the lack of a higher effect on GY of any parameter measured in the early stages of the crop.

In conclusion, it appears that selection for $\delta^{13} \mathrm{C}$ will continue to be controversial because the direction in which selection is needed still depends on the environmental conditions where the crop will grow. Selecting for lower (more negative) $\delta^{13} \mathrm{C}$ at different growth stages seems quite useful to identify genotypes exhibiting improved final grain yield, especially under mild water limiting conditions, but it does not have the same impact under well-watered conditions. On the other hand, the use of $\delta^{13} \mathrm{C}$ to select for higher early vigour only seems of interest under certain conditions such as good water supply. In addition, $\delta^{15} \mathrm{~N}$ also adds further advantages in selection for grain yield. Regarding $\delta^{18} \mathrm{O}$, it does not appear, at least for the mild water stress conditions of the present experiment, a suitable trait for breeding. In fact, although $\delta^{18} \mathrm{O}$ was already proposed as a target for selection more than a decade ago, relatively few papers have been published that discuss this further. Finally, the use of early vigour traits seems useful for managing water resources in the soil by increasing the potential for later growth but it does not impact directly on the final GY of wheat.

This study was supported by a workpackage of the European Commission research project TRITIMED (INCO-CT-2004-509136). It was also partially supported by the European research project OPTIWHEAT (INCO STREP no. 015460) and by the Spanish Ministry of Science and Technology project, AGL200913539C02-01 (subprograma AGR).

\section{REFERENCES}

Acevedo, E. (1993). Potential of carbon isotope discrimination as a selection criterion in barley breeding. In Stable Isotopes and Plant Carbon-Water Relations (Eds J.R. Ehleringer, A. E. Hall \& G. D. Farquhar), pp. 399-417. New York: Academic Press. 
Acevedo, E. H., Silva, P. C., Silva, H. R. \& Solar, B. R. (1999). Wheat production in Mediterranean environments. In Wheat: Ecology and Physiology of Yield Determination (Eds E. H. Satorre \& G. A. Slafer), pp. 295-332. New York: Food Products Press.

Aparicio, N., Villegas, D., Araus, J. L., Blanco, R. \& Royo, C. (2002). Seedling development and biomass as affected by seed size and morphology in durum wheat. Journal of Agricultural Science, Cambridge 139, 143-150.

Araus, J. L. (2004). The problem of sustainable water use in the Mediterranean and research requirements for agriculture. Annals of Applied Biology 144, 259-272.

Araus, J. L., Alegre, L., Tapia, L. \& Calafell, R. (1986). Relationship between leaf structure and gas exchange in wheat leaves at different insertion levels. Journal of Experimental Botany 37, 1323-1333.

Araus, J. L., Tapia, L. \& Alegre, L. (1989). The effect of changing sowing date on leaf structure and gas exchange characteristics of wheat flag leaves grown under Mediterranean conditions. Journal of Experimental Botany 40, 639-646.

Araus, J. L., Amaro, T., Zuhair, Y. \& Nachit, M. M. (1997). Effect of leaf structure and water status on carbon isotope discrimination in field-grown durum wheat. Plant Cell and Environment 20, 1484-1494.

Araus, J. L., Amaro, T., Casadesús, J., Asbatl, A. \& NACHIT, M. M. (1998). Relationships between ash content, carbon isotope discrimination and yield in durum wheat. Australian Journal of Plant Physiology 25, 835-842.

Araus, J. L., Slafer, G. A., Reynolds, M. P. \& Royo, C. (2002). Plant breeding and water relations in $\mathrm{C} 3$ cereals: what should we breed for? Annals of Botany, London 89, 925-940.

Araus, J. L., Villegas, D., Aparicio, N., García Del Moral, L. F., El Hani, S., Rharrabti, Y., Ferrio, J. P. \& Royo, C. (2003). Environmental factors determining carbon isotope discrimination and yield in durum wheat under Mediterranean conditions. Crop Science 43, 170-180.

Araus, J. L., Slafer, G. A., Royo, C. \& Serret, M. D. (2008). Breeding for yield potential and stress adaptation in cereals. Critical Reviews in Plant Science 27, 377-412.

Austin, R. B. (1999). Yield of wheat in the United Kingdom: recent advances and prospects. Crop Science 39, 1604-1610.

Bänzıger, M., Edmeades, G. O., Beck, D. \& Bellon, M. (2000) Breeding for Drought and Nitrogen Stress Tolerance in Maize: From Theory to Practice. Mexico, DF: CIMMYT.

Barbour, M. M. (2007). Stable oxygen isotope composition of plant tissue: a review. Functional Plant Biology 34, 83-94.

Barbour, M. M., Fischer, R. A., SAyre, K. D. \& Farquhar, G. D. (2000a). Oxygen isotope ratio of leaf and grain material correlates with stomatal conductance and grain yield in irrigated wheat. Australian Journal of Plant Physiology 27, 625-637.

Barbour, M. M., Schurr, U., Henry, B. K., Chin Wong, S. \& FARQUHAR, G. D. (2000b). Variation in the oxygen isotope ratio of phloem sap sucrose from castor bean. Evidence in support of the Péclet effect. Plant Physiology 123, 671-679.
Bıum, A. (2006). Drought adaptation in cereal crops: a prologue. In Drought Adaptation in Cereals (Ed. J.M. Ribaut), pp. 3-15. New York: The Harworth Press, Inc.

BıUM, A. (2009). Effective use of water (EUW) and not water-use efficiency (WUE) is the target of crop yield improvement under drought stress. Field Crops Research 112, 119-123.

Bort, J., Araus, J. L., Hazzam, H., Grando, S. \& Ceccarelli, S. (1998). Relationships between early vigour, grain yield, leaf structure and stable isotope composition in field grown barley. Plant Physiology and Biochemistry 36, 889-897.

Botwright, T.L., Condon, A. G., Rebetzke, G.J. \& RiCHARDS, R. A. (2002). Field evaluation of early vigour for genetic improvement of grain yield in wheat. Australian Journal of Agricultural Research 53, 1137-1145.

Cabrera-Bosquet, L., Molero, G., Nogués, S. \& Araus, J. L. (2009). Water and nitrogen conditions affect the relationships of $\Delta^{13} \mathrm{C}$ and $\Delta^{18} \mathrm{O}$ with gas exchange and growth in durum wheat. Journal of Experimental Botany 60, 1633-1644.

Cabrera-Bosquet, L., Albrizio, R., Nogués, S. \& Araus, J. L. (2011). Dual $\Delta^{13} \mathrm{C} / \delta^{18} \mathrm{O}$ response to water and nitrogen availability and its relationship with yield in fieldgrown durum wheat. Plant Cell and Environment 34, 418-433.

Cernusak, L. A., Wong, S.C. \& Farquhar, G. D. (2003). Oxygen isotope composition of phloem sap in relation to leaf water in Ricinus communis. Functional Plant Biology 30, 1059-1070.

Condon, A. G. (2012). Comparative evaluation of oxygen isotope composition and carbon isotope discrimination in selecting for greater agronomic water use efficiency in wheat. In Greater Agronomic Water Use Efficiency in Wheat and Rice using Carbon Isotope Discrimination (Ed. International Atomic Energy Agency), pp. 267-275. IAEA-TECDOC-1671. Vienna, Austria: International Atomic Energy Agency.

Condon, A. G. \& Richards, R. A. (1992). Broad sense heritability and genotype $\times$ environment interaction for carbon isotope discrimination in field-grown wheat. Australian Journal of Agricultural Research 43, 921-934.

Condon, A. G., Richards, R. A., Rebetzke, G. J. \& FARQUHAR, G.D. (2002). Improving intrinsic water-use efficiency and crop yield. Crop Science 42, 122-131.

Condon, A. G., Richards, R. A., Rebetzke, G. J. \& FARQUHAR, G.D. (2004). Breeding for high water-use efficiency. Journal of Experimental Botany 55, 2447-2460.

Coque, M., Bertin, P., Hirel, B. \& Gallais, A. (2006). Genetic variation and QTLs for ${ }^{15} \mathrm{~N}$ natural abundance in a set of maize recombinant inbred lines. Field Crops Research 97, 310-321.

Craig, H. \& Gordon, L. I. (1965). Deuterium and oxygen 18 variations in the ocean and marine atmosphere. In Stable Isotopes in Oceanographic Studies and Paleotemperatures (Ed. E. Tongiorgi), pp. 9-130. Pisa, Italy: Consiglio Nazionale Delle Ricerche Laboratorio Di Geologia Nucleare.

Culuis, B. R., Smith, A. B. \& CoOmbes, N. E. (2006). On the design of early generation variety trials with correlated 
data. Journal of Agricultural, Biological, and Environmental Statistics 11, 381-393.

Dongmann, G., NurnberG, H. W., Forstel, H. \& Wagener, K. (1974). On the enrichment of $\mathrm{H}_{2}^{18} \mathrm{O}$ in the leaves of transpiring plants. Radiation and Environmental Biophysics 11, 41-52.

EHDAIE, B. \& WAINES, J. G. (1993). Variations in water use efficiency and its components in wheat: I. Well-watered pot experiment. Crop Science 33, 294-299.

Ellis, R.P., Forster, B.P., Waugh, R., Bonar, N., Handley, L. L., Robinson, D., Gordon, D. C. \& Powell, W. (1997). Mapping physiological traits in barley. New Phytologist 137, 149-157.

Ellis, R. P., Forster, B.P., Gordon, D. C., Handley, L. L., Keith, R. P., Lawrence, P., Meyer, R., Powell, W., Robinson, D., SCRIMGeOUR, C.M., YounG, G. \& Thomas, W. T. B. (2002). Phenotype/genotype associations for yield and salt tolerance in a barley mapping population segregating for two dwarfing genes. Journal of Experimental Botany 53, 1163-1176.

Evans, L. T., Wardlaw, I. F. \& Fischer, R. A. (1975). Wheat. In Crop Physiology; Some Case Histories (Ed. L. T. Evans), pp. 101-149. London: Cambridge University Press.

FALCONER, D. S. \& MACKAY, T. F. C. (1996). Introduction to Quantitative Genetics, 4th edn, New York: Longman.

Farquhar, G. D. \& Lloyd, J. (1993). Carbon and oxygen isotope effects in the exchange of carbon dioxide between terrestrial plants and the atmosphere. In Stable Isotopes and Plant Carbon-Water Relations (Eds J. R. Ehleringer, A. E. Hall \& G. D. Farquhar), pp. 47-70. San Diego, USA: Academic Press, Inc.

Farquhar, G. D. \& Richards, R. A. (1984). Isotopic composition of plant carbon correlates with water-use-efficiency of wheat genotypes. Australian Journal of Plant Physiology 11, 539-552.

Farquhar, G. D., Firth, P. M., Wetselaar, R. \& Weir, B. (1980). On the gaseous exchange of ammonia between leaves and the environment: determination of the ammonia compensation point. Plant Physiology 66, 710-714.

Farquhar, G. D., Cernusak, L. A. \& Barnes, B. (2007). Heavy water fractionation during transpiration. Plant Physiology 143, 11-18.

Febrero, A., Blum, A., Romagosa, I. \& Araus, J. L. (1993). Relationship between carbon isotope discrimination in field grown barley and some physiological traits of juvenile plants in growth chamber. In Supplemental Abstracts of the First International Crop Science Congress (Eds D. R. Buxton, R. Shibles, R. A. Forsberg, B. L. Blad, K. H. Asay, G. M. Paulsen \& R. F. Wilson), pp. 717-726, 14-22 July 1992, lowa State Center, Ames, Iowa, USA. Madison, WI: CSSA.

Ferrio, J. P., Mateo, M. A., Bort, J., Abdalla, O., Voltas, J. \& Araus, J. L. (2007). Relationships of grain $\delta^{13} \mathrm{C}$ and $\delta^{18} \mathrm{O}$ with wheat phenology and yield under water-limited conditions. Annals of Applied Biology 150, 207-215.

FISCHER, R. A. (2007). Understanding the physiological basis of yield potential in wheat. Journal of Agricultural Science, Cambridge 145, 99-113.

Fischer, R. A., Rees, D., Sayre, K. D., Lu, Z-M., Condon, A. G. $\&$ SAAVEDRA, A. L. (1998). Wheat yield progress associated with higher stomatal conductance and photosynthetic rate and cooler canopies. Crop Science 38, 1467-1475.

Foulkes, M. J., Slafer, G. A., Davies, W. J., Berry, P.M., Sylvester-Bradley, R., Martre, P., Calderinl, D. F., Griffiths, S. \& ReYNOLDS, M.P. (2011). Raising yield potential of wheat. III. Optimizing partitioning to grain while maintaining lodging resistance. Journal of Experimental Botany 62, 469-486.

García Del Moral, L. F., Rharrabti, Y., Villegas, D. \& Royo, C. (2003). Evaluation of grain yield and its components in durum wheat under Mediterranean conditions. Agronomy Journal 95, 266-274.

Handley, L. L., Robinson, D., Forster, B.P., Ellis, R. P., Scrimgeour, C. M., Gordon, D. C., Nero, E. \& Raven, J. A. (1997). Shoot $\delta^{15} \mathrm{~N}$ correlates with genotype and salt stress in barley. Planta 201, 100-102.

Hubick, K.T. \& Farquhar, G. D. (1989). Carbon isotope discrimination and the ratio of carbon gained to water lost in barley cultivars. Plant, Cell and Environment 12, 795-804.

ICARDA (2004). ICARDA Annual Report 2003. Aleppo, Syria: ICARDA.

Kehel, Z., Habash, D.Z., Gezan, S.A., Welham, S. J. \& NACHIT, M.M. (2010). Estimation of spatial trend and automatic model selection in augmented designs. Agronomy Journal 102, 1542-1552.

Kelly, A. M., Smith, A. B., Eccleston, J.A. \& Cullis, B. R. (2007). The accuracy of varietal selection using factor analytic models for multi-environment plant breeding trials. Crop Science 47, 1063-1070.

LatiRI-Souki, K., NortclifF, S. \& Lawlor, D.W. (1998). Nitrogen fertilizer can increase dry matter, grain production and radiation and water use efficiencies for durum wheat under semi-arid conditions. European Journal of Agronomy 9, 21-34.

Latiri, K., Lhomme, J. P., Annabi, M. \& Setter, T. L. (2010). Wheat production in Tunisia: Progress, inter-annual variability and relation to rainfall. European Journal of Agronomy 33, 33-42.

Maccaferri, M., Sanguineti, M. C., Demontis, A., El-Ahmed, A., Garcia Del Moral, L., Maalouf, F., Nachit, M., Nserallah, N., Ouabbou, H., Rhouma, S., Royo, C., Villegas, D. \& Tuberosa, R. (2010). Association mapping in durum wheat grown across a broad range of water regimes. Journal of Experimental Botany 62, 409-438.

Maydup, M. L., Graciano, C., Guiamet, J. J. \& Tambussi, E. A. (2012). Analysis of early vigour in twenty modern cultivars of bread wheat (Triticum aestivum L.). Crop and Pasture Science 63, 987-996.

Merah, O., Deleéns, E. \& Monneveux, P. (1999). Grain yield, carbon isotope discrimination, mineral and silicon content in durum wheat under different precipitation regimes. Physiologia Plantarum 107, 387-394.

Merah, O., Deleéns, E., Souyris, I., Nachit, M. \& Monneveux, P. (2001a). Stability of carbon isotope discrimination and grain yield in durum wheat. Crop Science 41, 677-681.

Merah, O., Monneveux, P. \& Deléens, E. (2001b). Relationships between flag leaf carbon isotope discrimination and several morpho-physiological traits in durum 
wheat genotypes under Mediterranean conditions. Environmental and Experimental Botany 45, 63-71.

Morgan, J.A., Lecain, D. R., MccalG, T.N. \& Quick, J. S. (1993). Gas exchange, carbon isotope discrimination and productivity in winter wheat. Crop Science 33, 178-186. Nachit, M. M., Elouafi, I., Pagnotta, M. A., El Saleh, A., lacono, E., Labhilili, M., Asbati, A., Azrak, M., Hazzam, H., Benscher, D., Khairallah, M., Ribaut, J.-M., Tanzarella, O. A., Porceddu, E. \& Sorrells, M. E. (2001). Molecular linkage map for an intraspecific recombinant inbred population of durum wheat (Triticum turgidum L. var. durum). Theoretical and Applied Genetics 102, 177-186.

Parry, M.A. J., Reynolds, M., Salvucci, M. E., Raines, C., Andralojc, P. J., Zhu, X-G., Price, G. D., Condon, A. G. \& FURBANK, R. T. (2011). Raising yield potential of wheat. II. Increasing photosynthetic capacity and efficiency. Journal of Experimental Botany 62, 453-467.

Passioura, J. B. (2002). Environmental biology and crop improvement. Functional Plant Biology 29, 537-546.

Payne, R. W., Murray, D. A., Harding, S. A., Baird, D. B. \& SoutAR, D. M. (2009). GenStat for Windows. Introduction, 12th edn, Hemel Hempstead, UK: VSN Int.

Pritchard, E.S. \& GuY, R. D. (2005). Nitrogen isotope discrimination in white spruce fed with low concentrations of ammonium and nitrate. Trees - Structure and Function 19, 89-98.

RaimanovÁ, I. \& Haberle, J. (2010). The effects of differentiated water supply after anthesis and nitrogen fertilization on $\delta^{15} \mathrm{~N}$ of wheat grain. Rapid Communications in Mass Spectrometry 24, 261-266.

RaO, R.C. N., Udayakumar, M., Farquhar, G. D., TAlwar, H. S. \& Prasad, T. G. (1995). Variation in carbon isotope discrimination and its relationship to specific leaf area and ribulose-1,5-bisphosphate carboxylase content in groundnut genotypes. Australian Journal of Plant Physiology 22, 545-551.

Rebetzke, G.J., Condon, A. G., Richards, R. A. \& FARQUHAR, G.D. (2002). Selection for reduced carbon isotope discrimination increases aerial biomass and grain yield of rainfed bread wheat. Crop Science 42, 739-745.

Rebetzke, G. J., Bruce, S. E. \& KirkegaArd, J. A. (2005). Longer coleoptiles improve emergence through crop residues to increase seedling number and biomass in wheat (Triticum aestivum L.). Plant Soil 272, 87-100.

Rebetzke, G. J., Condon, A. G., Farquhar, G. D., Appels, R. \& RiCHARDS, R. A. (2008). Quantitative trait loci for carbon isotope discrimination are repeatable across environments and wheat mapping populations. Theoretical and Applied Genetics 118, 123-137.

Reynolds, M., Condon, A. G., Rebetzke, G. J. \& Richards, R. A. (2004). Evidence for excess photosynthetic capacity and sink-limitation to yield and biomass in elite spring wheat. In New Directions for a Diverse Planet. Proceedings of the 4th International Crop Science Congress (Eds T. Fischer, N. Turner, J. Angus, L. Mclntyre, M. Robertson, A. Borrell \& D. Lloyd). Gosford, Australia: The Regional Institute Ltd. Available from: http://www.cropscience.org.au/icsc2004/ poster/2/7/3/1315_reynoldsmp.htm (verified 25 March 2013).
Reynolds, M., Foulkes, J.M., Slafer, G. A., Berry, P., Parry, M. A. J., SnAPE, J. W. \& Angus, W. J. (2009). Raising yield potential in wheat. Journal of Experimental Botany 60, 1899-1918.

Reynolds, M., Bonnett, D., Chapman, S. C., Furbank, R. T., Manès, Y., Mather, D. E. \& Parry, M. A. J. (2011). Raising yield potential of wheat. I. Overview of a consortium approach and breeding strategies. Journal of Experimental Botany 62, 439-452.

Richards, R.A. (2006). Physiological traits used in the breeding of new cultivars for water-scarce environments. Agricultural Water Management 80, 197-211.

Richards, R. A. \& LuKaCs, Z. (2002). Seedling vigour in wheat-sources of variation for genetic and agronomic improvement. Australian Journal of Agricultural Research 53, 41-50.

Richards, R. A., López-Castañeda, C., Gomez-Macpherson, H. \& Condon, A. G. (1993). Improving the efficiency of water use by plant breeding and molecular biology. Irrigation Science 14, 93-104.

Richards, R. A., Condon, A. G. \& Rebetzke, G. J. (2001). Traits to improve yield in dry environments. In Application of Physiology in Wheat Breeding (Eds M. P. Reynolds, J. I. Ortiz-Monasterio \& A. McNab), pp. 88-100. México DF: CIMMYT.

Richards, R.A., Rebetzke, G. J., Condon, A. G., \& Van Herwaarden, A. F. (2002). Breeding opportunities for increasing the efficiency of water use and crop yield in temperate cereals. Crop Science 42, 111-121.

Robinson, D., Handley, L. L., Scrimgeour, C.M., Gordon, D. C., Forster, B. P. \& Ellis, R. P. (2000). Using stable isotope natural abundances $\left(\delta^{15} \mathrm{~N}\right.$ and $\left.\delta^{13} \mathrm{C}\right)$ to integrate the stress responses of wild barley (Hordeum spontaneum C. Koch.) genotypes. Journal of Experimental Botany 51, 41-50.

Saurer, M., Aellen, K. \& Siegwolf, R. (1997). Correlating $\delta^{13}$ C and $\delta^{18} \mathrm{O}$ in cellulose of trees. Plant, Cell and Environment 20, 1543-1550.

Sayre, K. D., Acevedo, E. \& Austin, R. B. (1995). Carbon isotope discrimination and grain yield for three bread wheat germplasm groups grown at different levels of water stress. Field Crops Research 41, 45-54.

Slafer, G. A. \& Araus, J. L. (2007). Physiological traits for improving wheat yield under a wide range of conditions. In Scale and Complexity in Plant Systems Research: Gene-Plant-Crop Relations (Eds J.H. J. Spiertz, P. C. Struik and H. H. van Laar), pp. 147-156. Dordrecht: Springer.

Slafer, G. A., Araus, J. L. \& Richards, R. A. (1999). Physiological traits that increase the yield potential of wheat. In Wheat: Ecology and Physiology of Yield Determination (Eds E. H. Satorre \& G. A. Slafer), pp. 379-415. New York: Food Products Press.

SMART, D. R. \& BLOOM, A.J. (2001). Wheat leaves emit nitrous oxide during nitrate assimilation. Proceedings of the National Academy of Scinces, USA 98, 7875-7878.

Serret, M. D., Ortiz-Monasterio, I., Pardo, A. \& Araus, J. L. (2008). The effects of urea fertilisation and genotype on yield, nitrogen use efficiency, $\delta^{15} \mathrm{~N}$ and $\delta^{13} \mathrm{C}$ in wheat. Annals of Applied Biology 153, 243-257. 
Tambussi, E. A., Nogués, S. \& Araus, J. L. (2005a). Ear of durum wheat under water stress: water relations and photosynthetic metabolism. Planta 221, 446-458.

Tambussi, E. A., Nogués, S., Ferrio, J. P., Voltas, J. \& Araus, J. L. (2005b). Does higher yield potential improve barley performance in Mediterranean conditions? A case study. Field Crops Research 91, 149-160.

Tambussi, E. A., Bort, J. \& Araus, J.L. (2007). Water use efficiency in $\mathrm{C}_{3}$ cereals under Mediterranean conditions: a review of physiological aspects. Annals of Applied Biology 150, 307-321.

Trethowan, R. M., Van Ginkel, M. \& Rajaram, S. (2002). Progress in breeding wheat for yield and adaptation in global drought affected environments. Crop Science 42, 1441-1446.

Villegas, D., Aparicio, N., Nachit, M.M., Araus, J. L. \& Royo, C. (2000). Photosynthetic and developmental traits associated with genotypic differences in durum wheat yield across the Mediterranean basin. Australian Journal of Agricultural Research 51, 891-901.

YAKIR, D. (1992). Variations in the natural abundance of oxygen-18 and deuterium in plant carbohydrates. Plant, Cell and Environment 15, 1005-1020.

YAKIR, D. \& DenIRO, M.J. (1990). Oxygen and hydrogen isotope fractionation during cellulose metabolism in Lemna gibba. L. Plant Physiology 93, 325-332.

YAKIR, D., DenIRO, M. J. \& GAT, J. R. (1990). Natural deuterium and oxygen-18 enrichment in leaf water of cotton plants grown under wet and dry conditions-evidence for water compartmentation and its dynamics. Plant, Cell and Environment 13, 49-56.

Yousfi, S., Serret, M.D. \& Araus, J. L. (2009). Shoot $\delta^{15} \mathrm{~N}$ gives a better indication than ion concentration or $\Delta^{13} \mathrm{C}$ of genotypic differences in the response of durum wheat to salinity. Functional Plant Biology 36, 144-155. 